\title{
Rezumate
}

\section{Zilele Institutului pentru Ocrotirea Mamei și Copilului „Prof. Dr. Alfred Rusescu“, București}

\section{INCIDENȚA RESTRICṬIEI DE CREŞTERE INTRAUTERINĂ ÎN CLINICA IOMC "GHEORGHE POLIZU“}

Silvia Maria Stoicescu ${ }^{1}$, Anca Teodora Tranca ${ }^{2}$, Adina Georgescu ${ }^{3}$

'UMF „Carol Davila“, București

2,3 Secția Neonatologie, IOMC „Prof. Dr. Alfred

Rusescu“" București

Introducere. Nou-născutul cu restricție de creştere intrauterină se consideră ca fiind nou-născutul cu greutate la naştere sub 2 deviații standard sau sub percentila 10\% pentru vârsta de gestație. Aproximativ 3-10\% din numărul total de sarcini sunt asociate cu RCIU. Rata mortalității perinatale este de 5-20 ori mai mare la feții cu RCIU, morbiditatea severă atât pe termen scurt, cât şi pe termen lung este observată la jumătate din nou-născuții care supraviețuiesc.

Obiectiv. Incidența restricției de creştere intrauterină la nou-născuții prematuri cu greutate la naştere $<1.500 \mathrm{~g}$.

Material şi metodă. Studiu retrospectiv în care s-au analizat prematurii cu greutate la naştere $<1.500 \mathrm{~g}$ efectuat în clinica de Neonatologie IOMC "Gheorghe Polizu“ în perioada 01.01.2011-31.12.2013. S-au urmărit: factorii socioeconomici (mediul de proveniență, vârsta mamei, consumul de alcool, droguri, malnutriție anterior sarcinii); factori materni (boli cronice pulmonare, cardiace, renale, endocrine, boala trombotică, paritate), factori placentari (decolare de placentă, infarct, placenta praevia) şi factori fetali (infecții congenitale, anomalii cromozomiale şi sarcină multiplă).

Rezultate. Prematurii cu RCIU au prezentat frecvent asfixie la naştere deoarece tolerează cu dificultate stresul naşterii şi prezintă risc crescut pentru multiple complicații postnatale: hemoragie pulmonară, hipertensiune pulmonară, hemoragii intraventriculare grad II-IV, enterocolită ulcero-necrotică şi tulburări metabolice.

Concluzii. Antenatal este esențial diagnosticul corect, determinarea factorilor de risc şi apariția complicațiilor. Momentul naşterii este foarte important. Nou-născutul trebuie extras atunci când este maturat pulmonar sau când profilul biofazic arată semne de suferință fetală. Astfel, co- laborarea între obstetrician şi neonatolog este, de asemenea, extrem de importantă.

Cuvinte cheie: prematur, RCIU, indice ponderal, morbiditate, mortalitate

The incidence of intrauterine growth restriction in the Institute of Mother and Child "Gheorghe Polizu“

Introduction. The infant with intrauterine growth restriction is considered the infant with a birth weight under two standard deviation or under the 10th percentile for gestational age. About 3 to $10 \%$ from all pregnancies are associated with growth restriction. The perinatal mortality rate is for 5 to 20 times higher in the IUGR fetuses, severe morbidity both short term and long term is seen in half of the surviving infants.

Objective. The incidence of intrauterine growth restriction in preterm infants with birth weight under 1,500 grams.

Material and methods. Retrospective study in which there were analyzed preterm with birth weight under 1,500 grams performed in the neonatology department of the Institute of Mother and Child "Gheorge Polizu" during 01.01.2011-31.12.2013. There were noted: socio-economic factors (area of origin, maternal age, alcohol, drugs, malnutrition before pregnancy); maternal factors (chronic lung disease, cardiac, renal, endocrine, thrombotic disease, parity), placental factors (abruption placenta, infarction, placenta praevia) and fetal factors (congenital infections, chromosomal abnormalities and multiple pregnancy).

Results. Preterm with IUGR have often had birth asphyxia because they tolerate with difficulty the stress of birth and they have increased risk for multiple postnatal complications: pulmonary hemorrhage, pulmonary hypertension, intra ventricular hemorrhage, necrotizing enterocolitis and metabolic disorders.

Conclusions. Correct antenatal diagnosis is essentially, the determination of the risk factors and complications. The moment of birth is very important. The newborn should be extracted when the lung is matured or when the biofazic profile shows signs of fetal distress. The collaboration between obstetrician and neonatologist is also very important.

Keywords: preterm, IUGR weight index, morbidity, mortality 


\section{FACTORI DE RISC ŞI CONSECINȚELE HEMORAGIILOR PERI-INTRAVENTRICULARE LA PREMATURI}

loana Alina Anca ${ }^{1,2}$, Mirela Ritivoiu'1,2, Florin Brezan ${ }^{1,2}$, Beata Acs ${ }^{1}$, loana Codreanu ${ }^{1}$, Diana Goran ${ }^{1}$, Lucica Ghiță2

'Departamentul de Pediatrie, UMF ",Carol Davila“", București

2IOMC „Prof. Dr. Alfred Rusescu“, București

Obiective. Pornind de la numeroasele observații privind afectarea neurologică a prematurilor, secundară hemoragiei peri-intraventriculare (HPIV), am efectuat un studiu prospectiv în perioada 2009-2012, al cărui obiectiv principal este determinarea ecografică a prevalenței diverselor grade de HPIV, a factorilor de risc asociați şi a efectelelor asupra dezvoltării neuro-psihomotorii pe o perioadă de urmărire de 1 an.

Materiale şi metodă. Toți prematurii internați în IOMC în perioada menționată au fost examinați prin ecografie transfontanelară. Stratificarea cazurilor s-a făcut conform clasificarii Papile prin utilizarea unui protocol de examinare unic. Toți copiii incluşi în lotul de studiu au fost monitorizați din punct de vedere neurologic pe o perioadă de 1 an.

Rezultate. HPIV grad I şi II au reprezentat tipurile cele mai frecvente $(92,5 \%)$ spre deosebire de HPIV severe de grad IV (4,4\%). În cazurile HPIV de grad I şi II corelația cu dezvoltarea neuropsihică favorabilă a fost statistic semnificativă, la fel ca şi severitatea sechelelor neurologice asociată HPIV de grad IV.

Concluzii. Diagnosticul precoce şi stadializarea corectă a HPIV realizată prin screening ETF pot ameliora prognosticul neurologic şi planul de recuperare al prematurilor, oferind în acelaşi timp informații corecte părinților în ceea ce priveşte evoluția pe termen mediu şi lung.

Cuvinte cheie: hemoragie peri-intraventriculară, ecografie, factori de risc, prematur

\section{Risk factors and consequences of peri-intraventricular hemorrhages in preterm babies}

Objectives. From multiple observations of neurological impairment associated with prematurity, secondary to peri-intraventricular hemorrhages (PIVH), we performed a prospective study between 2009-2012, which main objective is to determine the prevalence of various degrees of PIVH diagnosed by head ultrasound, the associated risk factors and neuro-psychomotor developmental effects on a 1 year period of time.

Materials and methods. All infants hospitalized in IOMC in the above mentioned period were examined by transfontanelar ultrasound. Stratification was done accord- ing to the Papile's PIVH classification, using a common and unique protocol examination. All children included in the study group were neurologically monitored for a 12 month period.

Results. PIVH grade I and II were the most common types (92.5\%) as opposed to severe PIVH grade IV (4.4\%). In cases of grade I and II PIVH the favorable neuropsychiatric development was statistically significant, as well as the severity of neurological sequels associated with PIVH grade IV.

Conclusions. Early diagnosis and correct staging of PIVH using transfontanelar ultrasound screening may improve preterm's neurological outcome and recovery plan, as well as provide accurate information to parents regarding children's medium and long term evolution.

Keywords: peri-intra ventricular hemorrhages, ultrasound, risk factors, preterm

\section{TROMBOFILIA ŞI PREMATURITATEA}

Prof. Dr. Silvia Stoicescu, Dr. Daniela Ciobanu,

Dr. Anca Andrei

Sectia Neonatologie, IOMC „Alfred Rusecu“, UMF „Carol Davila“, București

Introducere. Trombofilia este cunoscută ca un dezechilibru al coagulării ce predispune la formarea trombilor. Boala de etiologie predominant genetică, dar şi favorizată de factorii exogeni, are manifestări frecvente în sarcină cu consecințe severe asupra gravidei şi fătului.

Scopul cercetării. Identificarea nou-născuților prematuri din mame cu trombofilie şi evidențierea în ce măsură această condiție patologică influnțează dezvoltarea hemoragiilor intraventriculare (HIV) la nou-născut.

Materiale şi metodă. Studiu retrospectiv pe o perioadă de 2 ani (ian. 2012-dec. 2013) pe un număr total de 136 prematuri cu VG 24-32 săptămâni, identifică 38 de mame cu trombofilie (istoric de tromboză profundă sau diagnostic prin testare genetică, sub tratament anticoagulant şi fără). S-au analizat copii din două loturi: lot cu PCA şi un lot martor, din punct de vedere al hemoragiilor cerebrale asocierea acestora cu trombofilia, VG, nevoia resuscitării la naştere şi evoluția postnatală. Toți prematurii incluşi în studiu au fost investigați ecografic pentru obiectivarea HIV şi PCA.

Rezultate. Incidența crescută a trombofiliei - 27,9\%. Copiii mamelor tratate în timpul sarcinii cu anticoagulate au atins vârste de gestație $>30$ de săptămâni şi au dezvoltat mai puțin HIV sau forme mult mai uşoare. PCA nu creşte riscul hemoragiilor cerebrale față de populația generală. Dezvoltarea HIV se corelează strâns cu vârsta de gestație, greutatea mică la naştere, necesitatea manevrelor de reanimare la naştere, riscul infecțios etc. 
Concluzii. Trombofilia nediagnosticată şi tratată conduce frecvent la naştere prematură. Hemoragia cerebrală este o consecință a prematurității. Ținând cont de etiologia predominant genetică noi studii sunt necesare pentru a pune în evidență relația tromboză-hemoragie la nou-născuții care moştenesc boala.

Cuvinte cheie: trombofilie, prematuritate, hemoragiile cerebrale la nou născut, PCA

\section{Thrombophilia and prematurity}

Introduction. Thrombophilia is known as an imbalance of coagulation that predispose to thrombus formation. Predominant etiology of the disease is genetic but also favored by exogenous factors. Thrombophilia has implications in pregnancy evolution with severe consequences on the pregnant woman and fetus.

Study purpose. To identify children born prematurely to mothers with thrombophilia and highlight the extent to which this pathological condition is involved in the development of intraventricular hemorrhage (IVH) in the newborn.

Materials and method. Retrospective study over a 2 years period (January 2012 - December 2013) on a no. total of 136 children born prematurely with gestational age = 24-32 weeks, identifies 38 mothers with thrombophilia (deep thrombosis history or diagnosis through genetic testing, with or without anticoagulant therapy) Children were analyzed in two groups: group with PDA and a control group in terms of their association with thrombophilia, cerebral hemorrhages, VG, need for resuscitation at birth and postnatal evolution. All infants included in the study were investigated by ultrasound for objectifying IVH and PDA .

Results. Increased incidence of thrombophilia $27.9 \%$. Children of mothers treated with anticoagulants during pregnancy reached higher gestational age $>30$ weeks, less developed IVH or forms less severe. PDA does not increase the risk of cerebral hemorrhage to the general population. Developing IVH correlates closely with gestational age, low birth weight, need for resuscitation maneuvers at birth, the risk of infection.

Conclusions. Thrombophilia undiagnosed and untreated ferecvent lead to premature birth. Cerebral hemorrhage is a consequence of prematurity. Given the predominantly genetic etiology new studies are needed to highlight the relationship thrombosis-hemorrhage in infants who inherit the disease.

Keywords: thrombophilia, prematurity, cerebral hemorrhage in the newborn, PDA

\section{PREVENIREA HEMORAGIEI INTRAVENTRICULARE LA PREMATURI}

Silvia Maria Stoicescu ${ }^{1}$, Leonard Năstase ${ }^{2}$

${ }^{1}$ UMF „Carol Davila“, București

${ }^{2}$ Sectia Neonatologie, IOMC „Prof. Dr. Alfred

Rusescu“, București

Introducere. Hemoragia intraventriculară (HIV) este o complicație majoră a patologiei nou-născuților prematuri sub 32 de săptămâni de gestație, respectiv sub $1.500 \mathrm{~g}$. Incidența este variabilă 13-65\% în diferite centre şi scade cu vârsta de gestație. Diferențele mari se datorează prezenței şi cumulării factorilor determinanți şi de risc.

Scopul studiului este de a evidenția factorii de risc asociați cu HIV care pot fi evitați sau ameliorați.

Material şi metodă. Studiul s-a realizat retrospectiv pe un lot de 93 de prematuri cu VG sub 32 de săptămâni născuți sau transferați în Clinica Neonatologie IOMC Polizu în perioada iunie 2013-iunie 2014. S-au analizat greutatea la naştere, vârsta de gestație, asistența medicală perinatală, managementul în secția de terapie intensivă neonatal.

Rezultate. Incidența hemoragiei intraventriculare în Clinica Neonatologie IOMC Polizu este de $61,3 \%-47,3 \%$ gradul I-II şi 14\% gradul III-IV. Factorii de risc indentificați sunt: hipoxie perinatală (cauze obstetricale, reanimare la naştere, insuficiența respiratorie) cu flux cerebral fluctuant (variații ale tensiunii arteriale, durere) şi flux cerebral crescut (hipercapnie, hiperinflare pulmonară), presiune venoasă cerebrală crescută (pneumotorax, insuficiență cardiacă postasfixie) şi tulburări de coagulare.

Concluzii. Factorii de risc pentru hemoragie intraventriculară pot fi clasificați astfel: intravasculari, vasculari şi extravasculari. Factorii intravasculari şi extravasculari pot fi influentați prin asistența medicală promptă, adecvată şi miniinvazivă. Factorii de risc HIV determinați de caracteristicile cerebrovasculare ale prematurului pot fi preveniți prin managementul antenatal (prevenirea prematurității, transfer in utero, corticoterapie).

Forma severă de HIV are risc crescut de sechele neurologice. Managementul adecvat ante- şi postnatal prin colaborarea echipei perinatale poate influența incidența hemoragiei intraventiculare severe.

Cuvinte cheie: nou-născut prematur, hemoragie intraventriculară, factor de risc, prevenție

\section{Prevention of intraventricular hemorrhage in preterm newborn}

Introduction. Intra ventricular hemorrhage (IVH) is a major complication of prematurity pathology under 32 weeks gestation, respectively less than 1,500 g. Incidence varies $13-65 \%$ in different centers and decreases with ges- 
tational age. Large differences due to the presence and cumulating determinants and risk factors.

The aim is to highlight the risk factors associated with HIV which can be avoided or reduced.

Material and methods. Retrospective study was conducted on a group of 93 preterm infants with 32 weeks gestational age inborn or out born of Neonatology Clinic IOMC Polizu in the period June 2013 - June 2014. Were analyzed birth weight, gestation age, perinatal nursing management in section neonatal intensive care.

Results. The incidence of IVH in Neonatology Clinic IOMC Polizu is $61.3 \%-47.3 \%$ grade I-II, and $14 \%$ grade III-IV. Risk factors identified was: peri natal hypoxia (obstetrical causes, resuscitation at birth, respiratory failure) with fluctuating cerebral flow (changes in blood pressure, pain) and increased cerebral blood flow (hypercapnia, pulmonary hiperinflare) increased cerebral venous pressure (pneumo thorax, decisions, with post-asphyxia heart failure) and coagulation disorders.

Conclusions. Risk factors for IVH can be classified as intravascular, vascular and extravascular. Intravascular and extravascular factors can be influenced by prompt, adequate and mini-invasive care. HIV risk factors correlated with the cerebrovasculare characteristics of preterm newborns can be prevented by antenatal management (prevention of prematurity, in utero transfer, corticosteroids).

Severe form of HIV have increased risk of neurological sequel. Ante-and postnatal appropriate management through perinatal team collaboration can influence the incidence of severe IVH.

Keywords: preterm newborn, intraventricular hemorrhage, risk factors, prevention

\section{MARKERI AI ASFIXIEI LA NAŞTERE}

Dr. Ramona Mohora ${ }^{1}$,

Prof. Dr. Silvia-Maria Stoicescu ${ }^{2}$

1,2UMF „Carol Davila“, București

${ }^{2}$ IOMC „Alfred Rusescu“, București

Introducere. Asfixia perinatală reprezintă cea mai frecventă cauză de mortalitate şi morbiditate a nou-născutului. Diagnosticul severității injuriei hipoxice perinatale se bazează în prezent pe o coroborare între datele anamnestice materne, ale evoluției sarcinii, investigațiilor paraclinice şi starea nou-născutului.

Scop. Identificarea markerilor hematologici ai asfixiei la naştere.

Cuprins. Hipoxia stimulează eliberarea de eritropoietină, care la rândul său induce producția de eritrocite la nivelul măduvei osoase. Studii din literatura internațională demonstrează că eritroblaştii (celule roşii nucleate), precursorii eritrocitelor, sunt prezenți în vasele placentare pe parcursul primei jumătăți a sarcinii şi nu se găsesc în mod obişnuit ulterior. Un număr crescut al acestora reflectă severitatea şi durata asfixiei, numărul lor poate creşte după o leziune hipoxică de scurtă durată dar agresivă, în urma eliberării din depozite.

Un număr crescut de eritroblaşti poate indica hipoxie fetală acută sau cronică, diabet gestațional, anemie fetală sau TORCH. Valoarea lor în sângele din cordonul ombilical la naştere reflectă efectele mediului intrauterin. Cum era de aşteptat, numărul absolut de eritroblaşti scade cu vârsta avansată a gestației.

Concluzii. Cunoaşterea şi identificarea acestor markeri este extrem de relevantă ca un indice al posibilelor leziuni cerebrale perinatale, şi, de asemenea, poate orienta asupra momentului instalării leziunii hipoxice.

Cuvinte cheie: asfixie, hipoxie perinatală, nou-născut, număr eritroblaşti, cordon ombilical

\section{Birth asphyxia markers}

Introduction. Perinatal asphyxia is the most common cause of mortality and morbidity of the newborn. Perinatal hypoxic injury severity diagnosis is currently based on a conjunction between maternal anamenestic data, the evolution of pregnancy, laboratory investigations and condition of the newborn.

Aim. Identification of hematological markers of asphyxia at birth.

Contents. Hypoxia stimulates the release of erythropoietin, which in turn induces the production of red blood cells in the bone marrow. Studies of international literature demonstrates that erythroblasts (nucleated red blood cells), red blood cell precursors are present in placental vessels during the first half of pregnancy and usually not found later. An increased number of them reflect the severity and duration of asphyxia, their number may increase after a hypoxic insult brief but aggressive after release from storage.

An increased number of erythroblasts may indicate acute or chronic fetal hypoxia, gestational diabetes, fetal anemia or TORCH. Their value in cord blood at birth reflect the effects of the intrauterine environment. As expected, the absolute number of erythroblasts decreases with advanced age of gestation.

Conclusions. Knowing and identifying these markers is highly relevant as a possible index of perinatal brain injury, and also can target the moment of hypoxic insult installation.

Keywords: asphyxia, perinatal hypoxia, newborn, number of erythroblasts, umbilical cord 


\section{VENTILATIIA MECANICĂ INVAZIVĂ VERSUS NONINVAZIVĂ LA PREMATURII CU}

\section{$\mathrm{GN}<1.500 \mathrm{G}$}

Prof. Univ. Dr. Silvia Maria Stoicescuㄹ,

Dr. Octaviana Cristea ${ }^{2}$, Dr. Adina Georgescu ${ }^{3}$

${ }^{1}$ UMF „Carol Davila“, București

${ }^{2,3}$ Clinica Neonatologie, IOMC „Prof. Dr. Alfred

Rusescu“, București

Obiectiv. Incidența complicațiilor ventilației mecanice invazive versus noninvazive la prematurii cu $\mathrm{Gn}<1.500 \mathrm{~g}$.

Material şi metodă. Studiu retrospectiv în care s-au analizat prematurii cu $\mathrm{Gn}<1.500 \mathrm{~g}$ cu sindrom de detresă respiratorie ventilați mecanic invaziv versus noninvaziv în Clinica Neonatologie - Departamentul Obstetrică-Ginecologie - IOMC „Alfred Rusescu“ în perioada 1 iunie 2013 31 iunie 2014 şi 1 iunie 2010 - 31 iunie 2011. S-au urmărit vârsta de gestație, greutatea la naştere, administrarea surfactantului (profilactic, terapeutic), modul de ventilație, morbiditate, complicații.

Rezultate. În perioada 1 iunie 2013 - 31 iunie 2014 în Departamentul Obstetrică-Ginecologie IOMC „Alfred Rusescu“ prematuri cu SDR au fost ventilați mecanic invaziv în modurile IPPV, SIMV, HFOV. Profilactic surfactantul a fost administrat imediat după naştere urmat de detubare şi aplicare de CPAPn sau presiune de distensie. S-a practicat aplicare de CPAPn imediat după naştere ca suport respirator inițial, reducând intubația şi ventilație mecanică invazivă. Hemoragia pulmonară, pneumotoraxul, displazia bronhopulmonară, hemoragia cerebrală gr. II-IV au fost prezente la prematurii ventilați mecanic invaziv.

Concluzii. Aplicarea de CPAPn imediat după naştere scade necesitatea ventilației mecanice invazive, incidența displaziei bronhopulmonare şi a hemoragiei cerebrale gr. II-IV.

Cuvinte cheie: prematuritate, SDR, ventilație mecanică invazivă, CPAPn

\section{Invasive versus noninvasive mechanical ventilation in very low and extremely low infants}

The objective of this study is to assess the outcome of very low and extremely low preterm infants invasive versus noninvasive mechanical ventilated.

Material and method. The retrospective study which analyzed premature infants with RDS in the Neonatology Clinic - Obstetrics-Gynecology Department - "Prof. Dr. Alfred Rusescu" Institute for Mother and Child Care between the 1st of June 2013 and the 31st of June 2014 and 1st of June 2010 and 31st of June 2011. The following were monitored: the infants' gestational age, birth weight, respirato- ry support, surfactant administration (prophylactic, therapeutic), morbidity, complications.

Results. Between the 1st of June 2013 and the 31st of June 2014 in the Obstetrics-Gynecology Department of Prof. Dr. Alfred Rusescu" Institute for Mother and Child Care the premature infants with respiratory distress syndrome were mechanical ventilated in IPPV, SIMV, HFOV mode.

Prophylactic surfactant was administered immediately after birth with extubation and application of CPAPn or distension pressure. We practiced CPAPn application immediately after birth as initial respiratory support with the decrease for the need of intubation and invasive mechanical ventilation. Pulmonary hemorrhage, pneumothorax, bronchopulmonary dysplasia, cerebral hemorrhage gr. II-IV were present in invasive mechanically ventilated infants.

Conclusions. CPAPn applied immediately after birth reduces the need for invasive mechanical ventilation, the incidence of bronchopulmonary dysplasia and cerebral hemorrhage gr. II-IV.

Keywords: prematurity, respiratory distress syndrome, invasive mechanical ventilation, CPAPn

\section{TERAPIA TRANSFUZIONALĂ ÎN PATOLOGIA PERINATALĂ}

Dr. Corina Posea

CTSMB

Transfuzia de sânge şi componente sanguine în patologia perinatală presupune o colaborare eficientă între medicul prescriptor şi medicii din centrul de transfuzie. Terapia transfuzională în acest caz se face cu componente sanguine speciale. Se iau în considerare următoarele aspecte în cazul transfuziei la pacienții neonatali: (1) volumul mai mic de sânge, (2) capacitatea metabolică redusă, (3) hematocritul mai ridicat şi (4) imaturitatea sistemului imunologic. Toate aceste aspecte sunt extrem de importante la efectuarea transfuziilor prenatale, la nou-născuții prematuri mici sau în cazul transfuziei de schimb.

Există un risc semnificativ de transmitere a CMV şi de apariție a bolii grefa contra gazdă, din acest motiv componentele sanguine trebuie să fie deleucocitate şi iradiate. Asigurarea necesarului transfuzional prin procesarea unei singure unități de sânge în mai multe unități componente cu volum mic are drept scop minimalizarea numărului de expuneri ale primitorului.

Există regulamente naționale specifice pentru testarea pre-transfuzională a grupelor de sânge şi a compatibilității la pacienții neonatali.

Siguranța transfuzională în patologia perinatală reprezintă un deziderat al sistemului de transfuzie deoarece 
aceşti pacienți prezintă cel mai mare potențial de supraviețuire pe termen lung.

\section{Transfusion therapy in perinatal pathology}

Transfusion of blood and blood components in perinatal pathology involves collaboration between the prescriber and doctors from the transfusion center. Transfusion therapy in this case is made with special blood components. The following factors must be considered when transfusing neonates: (1) smaller blood volume, (2) reduced metabolic capacity, (3) higher hematocrit and (4) immaturity of the immune system. All these issues are extremely important to perform prenatal transfusions in preterm small infants or exchange transfusion.

There is a significant risk of transmission of CMV and the occurrence of graft versus host disease, therefore blood components must be leucocyte depleted and irradiated. Providing the transfusion necessary by processing a single unit of blood in several parts with low volume units aims at minimizing the number of exposures of the recipient.

There are national regulations for testing pre-transfusion blood groups and compatibility neonatal patients.

Transfusion safety in perinatal pathology is a goal of transfusion system as these patients have the highest potential for long-term survival.

\section{PARAMETRI DE CREŞTERE PENTRU NOU-NĂSCUṬI PROVENIṬI DIN SARCINI CU TOXICOMANIE ŞI FIV}

\author{
Prof. Dr. Silvia-Maria Stoicescu ${ }^{1,2}$, \\ Dr. Doina Broscăuncianu² ${ }^{2}$ Dr. Anca Cabăț² \\ "UMF „Carol Davila”, Bucuresti \\ ${ }^{2} 10 \mathrm{MC}$, Alfred Rusescu“, Spitalul de Obstetrică \\ Ginecologie „Gh. Polizu“, București
}

Introducere. Dacă la început evoluția speciei umane era marcată de selecția naturală, în ultimele decenii, condițiile naturale şi socio-culturale (inclusiv progresele medicale) par să infuențeze variabilitatea biologică umană, contribuind la remodelarea antropologiei. Consumul ilicit de droguri în sarcină (adaptat tendințelor comportamentale specifice europene) şi fertilizarea in vitro (FIV) - tehnologie de reproducere umană asistată (mai uşor accesibilă în viitorul apropiat printr-o metoda Low cost - FIV promovată de un proiect internațional de cercetare „Walking Egg Project” pentru infertilitate în țări sărace) implică riscuri prin sarcini cu feți multipli, prematuritate, tulburări de creştere, morbiditate şi mortalitate neonatală.
Obiectiv. Stabilirea parametrilor de creştere în funcție de vârsta de gestație şi greutatea la naştere pentru nounăscuți proveniți din sarcini marcate de toxicomanie şi din sarcini obținute prin FIV.

Material şi metodă. Studiu retrospectiv realizat în IOMC Spital „Polizu“ pe o perioadă de 10 ani (2004-2013) pentru nou-născuti proveniți din sarcini marcate de toxicomanie $(n=40)$ şi o perioadă de 2 ani $(01.06 .2012$ 01.06.2014) pentru nou-născuți proveniți din sarcini obținute prin FIV $(n=92)$. Cele două loturi au fost comparate cu un lot martor $(n=90)$.

Rezultate. Prematurii (VG < 37 de săptămâni) au fost de 3,85 ori mai numeroşi în lot FIV şi de 1,82 ori în lot toxicomane decât în lot martor. RCIU (VG $\geq 37$ de săptămâni şi GN $<2.500 \mathrm{~g}$ ) a fost de 5,3 ori mai frecventă în lot toxicomane față de lot FIV şi lot martor.

Concluzii. Asocierea FIV cu prematuritatea (prin gemelaritate), ca şi asocierea consumului de droguri cu RCIU, constituie factori de risc pentru morbiditate neonatală. Promovarea măsurilor de prevenție care să evite consumul ilicit de droguri în sarcină însoțit de consecințele sale multiple şi grave, precum şi promovarea măsurilor de păstrare a fertilității naturale (ex. tratarea bolilor cu transmitere sexuală) ar fi de dorit pentru evoluția ființei umane în parametrii de normalitate pentru aceasta epocă.

\section{Growth parameters for newborns from drug abusing mothers and from IVF pregnancies}

Introduction. During the last decades the natural human evolution seems to be more and more influenced by social-cultural factors (including here the progress in medicine), by contrast to natural selection present at the beginnings of humanity, therefore contributing to anthropological remodelling. Drug abuse during pregnancy (following similar tendencies from other European countries) and IVF - assisted reproductive technology (more accessible in the near future through a low-cost method: "Walking Egg Project" - international research project regarding infertility in poor countries) are implying many risks - multiple gestations, prematurity, developmental issues, neonatal morbidity and mortality.

Objective. To analyse growth parameters by gestational age and birth weight for newborns from drug abusing mothers and for pregnancies obtained through IVF.

Material and methods. Retrospective study on newborns from "IOMC - Emergency Clinical Hospital of Obstetrics and Gynaecology Gh Polizu", Bucharest, during 10 years (2004-2013) for the newborns from drug addicted mothers (no $=40)$, respectively during 2 years $(01.06 .2012-$ 01.06.2014) for the newborns from IVF pregnancies (no = 92). Both groups have been compared to a witness group (no = 90). 
Results. Premature babies (GA $<37$ weeks) in the IVF group were 3,85 as many as ones in the control group, respectively 1.82 more frequent for the drug abusing mothers group. IUGR ( $G A \geq 37$ weeks and $B W<2,500 \mathrm{~g}$ ) was 5.3 times more frequent for the babies in the drug abusing mothers group compared to IVF group and the control group.

Conclusions. Association between IVF and prematurity (due to multiple gestations) and between drug abuse during pregnancy and IUGR are both risk factors for neonatal morbidity. It is desirable to support preventive measures like avoiding drug abuse during pregnancy (and all its multiple and serious consequences) and finding means for the protection of natural fertility (e.g. correct treatment for STD) for the benefit of human evolution in the normality ranges of this era.

\section{SCREENING-UL NEONATAL - SUCCESUL ÎN PREVENTIIE}

Dr. D. lorgulescu

IOMC „Alfred Rusescu“, București

IOMC Alfred Rusescu este recunoscut astăzi şi pentru derularea Programului național de screening neonatal. În România anului 2014 se depistează două boli: fenilcetonuria (PKU) şi hipotiroidismul congenitall (HC), ambele cu potențial de afectare a creierului în lipsa tratamentului inițiat precoce. Din acest punct de vedere suntem pe ultimul loc în UE unde, în țările civilizate, sunt diagnosticate peste 30 de boli.

În prezent avem o medie anuală de 180.000 nounăscuți; 2/3 dintre aceştia sunt testați în IOMC. Restul de $1 / 3$ revine celorlalte 4 centre de screening: Cluj, Timişoara, laşi, Tg. Mureş.

Dacă pacienții diagnosticați cu HC sunt tratați şi în rețeaua teritorială de endocrinologie, pacienții cu PKU - 84 în evidență - revin la doi medici pediatri, ajutați în reevaluare de doi specialişti în neuropsihiatrie infantilă şi un psiholog din ambulatoriul IOMC. Echipa este mică, efortul este mare, iar lipsa dieteticianului este greu de surmontat.

Fenilcetonuria este o boală metabolică, transmisă genetic, din categoria aminoacidopatiilor. Fiziopatologia PKU este centrată pe deficiența enzimei PAH sau a cofactorului $\mathrm{BH} 4$, rezultând hiperfenilalaninemia, cu efect toxic pe sistemul nervos. Nivelurile scăzute ale tirozinei afectează sinteza melaninei, a neurotransmițătorilor, a hormonilor tiroidieni.

Tratamentul PKU vizează reducerea aportului oral de fenilalanina şi asigurarea necesarului proteic cu substituient gratuit din Program. Din 2014 avem şi 3 pacienți PKU tratați cu Kuvan, echivalent al cofactorului BH4, acesta fiind benefic numai pacienților responsivi, cărora le îmbunătățeşte activitatea enzimei PAH.
Pacienții PKU diagnosticați la naştere sunt testați şi pentru deficiența de BH4, obiectiv neprevăzut în Program, realizat de noi prin colaborare cu specialişti din Zürich. 37 dintre pacienții noştri au determinată şi mutația genei PAH în acelaşi centru din Elveția.

Apreciem că succesul în preventive este dat de creşterea calității vieții pacientului PKU /familiei sale şi scăderea costurilor sociale, obiectiv realizat prin:

- stabilirea diagnosticului prin screening neonatal;

- asigurarea complianței familiei/pacientului;

- asigurarea produselor dietetice speciale gratuit, prin Program, constant si sigur.

\section{Neonatal screening - success in prevention}

IOMC "Alfred Rusescu“ is also known today for the National Neonatal Screening Program. In 2014 Romania two diseases are detected: PKU and HC, both presenting a potential high risk of brain damage if left untreated in the early stages. In the civilized countries, at birth, newborns are tested for minimum 30 diseases, which puts Romania in the last place among European countries.

Currently, the average of newborns in Romania is aprox. 180,000 . Two thirds of them are being tested at IOMC and one third is divided between the other four screening centers: Cluj, Timisoara, lasi and Tg. Mures.

While the $\mathrm{HC}$ diagnosed patients can also be treated and monitored in the endocrinology territorial network, the PKU patients - more exactly, 84 - are in the care of two pediatricians, assisted in reevaluation by two specialists in infantile neuropsychiatry and a psychologist at IOMC ambulatory. The team is small, the effort is big and the absence of a dietitian is difficult to overcome.

PKU is a metabolic disease, genetically transmitted, from the aminoacidopathies category. The pathophysiology of PKU is centered on the deficiency of PAH enzyme or of the $\mathrm{BH} 4$ cofactor, resulting in hyperphenylalanina with toxic effect on the nervous system. The low levels of tyrosine affects the synthesis of melanin, of the neurotransmitters and of the thyroid hormones.

The PKU treatment aims at reducing the oral intake of phenylalanine and provides the necessary protein with the free protein substitute from the program. Starting from 2014, we have three patients treated with Kuvan, equivalent of the $\mathrm{BH} 4$ cofactor, this treatment helping patients whose PAH enzyme activity is improved.

The patients diagnosed at birth with PKU are also tested for BH4 deficiency, an unexpected objective of the program, accomplished in a cooperation agreement with specialists from Zürich. Thirty-seven of our patients had the PAH gene mutation determined in the same center in Swizerland. 
We consider that the success in prevention is due to higher life quality of the PKU patients and their family and lower social costs, objective established through:

- Established diagnosis by neonatal screening;

- Assurance of compliance with family/patients;

- Ensuring the special dietetic products, freely offered in the program, in a constant and reliable way.

\section{LABORATORUL DE SCREENING NEONATAL PENTRU DEPISTAREA HIPOTIROIDIEI ŞI FENILCETONURIEI: TRECUT ŞI PERSPECTIVE}

Dr. Denisa Leu, Biochimist Corina Delia, Chimist Geanina Toma, Biolog Daniela Haidautu, Biolog Nicoleta Lăcătuș, Chimist Mihaela Cutieru IOMC „Alfred Rusescu“, București

Fenilcetonuria este o boală metabolică cu transmitere genetică recesivă, caracterizată printr-o tulburare în sinteza fenilalaninei.

Hipotiroidia este 0 afecțiune hormonală provocată de agenezia sau disgenezia glandei tiroide.

Interesul Institutului pentru Ocrotirea Mamei şi Copilului „Prof. Dr. Alfred Rusescu“ pentru depistarea hipotiroidiei şi fenilcetonuriei, datează din anul 1978 - Proiect pilot.

Laboratorul de screening din IOMC deserveste maternitatile din 29 de județe şi din Bucureşti.

Zilnic sunt înregistrați şi testați aproximativ 650 de copii. Astfel, copiii afectați au şansa de recuperare.

Activitatea de screening face parte integranța din Programul Național de Sănatătate PN VI intervenția „Screening neonatal pentru depistarea hipotiroidiei şi a fenilcetonuriei".

Tehnica de laborator constă în determinarea cantitativă a hTSH şi a PKU din dry spot prin FEIA (fluorometric enzyme immunoassay) $\mathrm{cu}$ ajutorul analizorului semiautomat Fluoroskan Ascent şi a sistemului automat Tecan Freedom Evo.

Perspective: introducerea de noi testări pentru $17-\mathrm{OH}$ progesteron şi galactoză.

\section{Neonatal screening laboratory for hypothyroidism and phenylketonuria: past and perspectives}

Phenylketonuria, a genetic metabolic disease recessive transmitted, is characterized by a disorder in the synthesis of phenylalanine.

Hypothyroidism is a hormonal disorder caused by agenesis or digenesis of the thyroid gland.

The interest of the Institute for Mother and Child Care "Prof. Dr. Alfred Rusescu" to detect hypothyroidism and phenylketonuria, dates back to 1978 - Pilot project.
IOMC Neonatal screening laboratory for hypothyroidism and phenylketonuria, test samples from 29 counties and Bucharest.

Daily are registered and tested about 650 children, giving the affected ones the chance of recovery.

Screening activity is part of the National Health Programme PN VI Intervention "Neonatal Screening for Hypothyroidism and Phenylketonuria".

Laboratory technique:

1. Quantitative fluorometric detection of human thyroid stimulation hormone (hTSH) from dried blood spot samples for reliable screening of congenital hypothyroidism $(\mathrm{CH})$, with Fluoroskan Ascent and Tecan Evo modular system automated;

2. Neonatal Phenylalanine is a chemical screening test with quantitative fluorometric determination of phenylalanine (Phe) from dried blood spot samples for the detection of phenylketonuria (PKU), with Fluoroskan Ascent and Tecan Evo modular system automated;

Perspectives: the introduction of new tests for $17-\mathrm{OH}$ progesterone and galactose.

\section{SCREENINGUL ŞI TRATAMENTUL RETINOPATIEI DE PREMATURITATE ÎN ROMÂNIA}

Cristina Nițulescuㄹ ${ }^{1}$, Constanța Nascutzy ${ }^{1}$, Ileana Vătavu ${ }^{1}$, Tatiana Ciomârtan ${ }^{1}$, Carmen Voicilă², Cristina Dumitru², Irina Stamatian ${ }^{1}$, Roxana Viuleț ${ }^{1}$

${ }^{1}$ IOMC „A. Rusescu“, Bucuresti

2IOMC „A. Rusescu“, Spitalul Clinic „Polizu“, București

Programul de screening şi tratament al retinopatiei de prematuritate (RP) este inițiat în România din 2002 la Institutul pentru Ocrotirea Mamei şi Copilului „Prof. Dr. Alfred Rusescu" (IOMC), la maternitățile din Bucureşti, iar din 2004 şi în alte centre regionale din țară (11 în prezent). în aceste centre se realizează şi screeningul copiiilor născuți în maternitățile din oraşele învecinate, care nu au un medic oftalmolog propriu. Pentru tratament din anul 2003 se foloseşte laserul diodă (în prezent în 8 centre) şi din 2010 injecția intraoculară cu anti-VEGF (în 3 centre). Sunt incluşi în screening toți copiii cu vârsta de gestație (VG) $\leq 34$ de săptămâni şi/sau greutatea la naştere $\leq 2.000$ grame.

Între anii 2002-2009, dintre cei 3.243 de copii examinați, $1806(55,6 \%)$ au fost diagnosticați cu RP, $482(14,9 \%)$ au necesitat laserterapie, cu rezultate favorabile în $85,3 \%$ din cazuri. 82 de copii din acest lot sunt nevăzători (39 de copii diagnosticați cu stadiul 5 la prima examinare şi 43 de copii cu evoluție nefavorabilă postlaser). Între anii 2010-2012, din 1206 de copii examinați, 54\% au avut RP, iar 202 (16,7\%) 
au necesitat tratament, cu evoluție favorabilă în $94 \%$ dintre cazuri, doar 12 copii (1\%) fiind nevăzători. Dintr-un lot de copii examinați în 2013, 49\% au avut RP şi 11\% au avut nevoie de tratament, însă niciunul nu este nevăzător. Extinderea programului de screening, cât şi inițierea tratamentului cu anti-VEGF, au ajutat la obținerea acestor rezultate favorabile.

Este obligatoriu menținerea programului de screening pentru RP în maternitățile de nivel 2 şi 3 şi în unitățile de terapie intensivă unde aceşti copii primesc îngrijire, ținând cont de evoluția nefavorabilă, de cele mai multe ori spre orbire în lipsa tratamentului. Rezultatele acestui program depind de o bună colaborare între medicii oftalmologi, neonatologi, pediatri, asistente şi părinți.

\section{Screening and treatment of retinopathy of prematurity in Romania}

The screening and treatment program of retinopathy of prematurity (ROP) in Romania started in 2002 at the Institute of Mother and Child Care (IOMC) at the maternities from Bucharest, and from 2004 at other regional centers (11 in all). In these centers are screened also the babies born in maternities from adjacent cities without a local ophthalmologist. The treatment is performed with diode laser from 2003 (8 centers) and with intraocular anti-VEGF ( 3 centers) from 2010. There are screened all the infants with gestational age $(\mathrm{GA}) \leq 34$ wks and/or birth weight $(\mathrm{BW}) \leq 2,000 \mathrm{gm}$.

Between 2002-2009, from those 3,243 infants screened, 1806 (55.6\%) were diagnosed with ROP, 482 (14.9\%) needed treatment with $85.3 \%$ favorable results. From this group, 82 infants are blind, (39 infants diagnosed with stage 5 ROP at the first examination and 43 infants with unfavorable evolution after laser therapy). Between 2010-2012, from 1206 infants tested, 54\% were diagnosed with ROP, and 202 were treated, with good results in $94 \%$, just 12 infants (1\%) being blind. From a group of infants examined in 2013, $49 \%$ were diagnosed with ROP and $11 \%$ needed treatment, but no one was blind. Both the extension of ROP screening program and the use of intraocular anti-VEGF determined these good results.

Considering the damaging evolution of ROP when left untreated, usually toward blindness, we strongly recommend ROP screening in the tertiary and second level units and in the neonatal intensive care units. ROP programs require good collaboration between neonatologists, ophthalmologists, pediatricians, nurses and parents.

\section{TERAPIA ANTI-VEGF ÎN RETINOPATIA DE PREMATURITATE}

Dr. Ileana Vătavuํㅗ Dr. Ramona Serban²,

Dr. Livia Sram², Dr. Nicoleta Zamfiroiu Avidis²,

Dr. A. Merticariu²

IOMC, București

${ }^{2}$ Spitalul Clinic de Urgențe Oftalmologice, București

Obiective. Prezentarea rolului VEGF în patogenia retinopatiei de prematuritate (RP) şi a terapiei anti-VEGF prin injecție intravitreană cu bevacizumab (Avastin), în cazurile de RP severă din zona I (RP posterioară agresivă: RP-PA).

Material şi metodă. Evaluarea a 27 de prematuri cu RP severă în zona I, născuți între noiembrie 2010 şi august 2013 şi tratați prin injecție intravitreană cu bevacizumab, privind vârsta gestațională (VG) şi greutatea la naştere (Gn), factorii de risc ai bolii, evoluția cazurilor la vârstele de 3, 6, 9 şi 12 luni de viață, necesitatea reintervențiilor şi apariția complicațiilor post-terapie.

Rezultate. S-a constatat că prematurii care au dezvoltat RP severă în zona I au avut VG şi $G n$ foarte mici ( $G n \leq 1.000 \mathrm{~g}$ în 49,15\% cazuri şi VG $\leq 28$ de săptămâni în 59,26\% cazuri).

Factorii de risc identificați în apariția RP severe au fost: oxigenoterapia cu $\mathrm{FiO} 2 \geq 40 \%$ în 96,3\% cazuri, anemia în $74,07 \%$ cazuri, transfuziile de sânge în $66,67 \%$ cazuri, ventilația mecanică în 59,26\% cazuri, septicemia în 22,22\% cazuri.

Injecțiile intravitreene cu bevacizumab s-au efectuat între 33 şi 35 de săptămâni postmenstruale în 62,98\% cazuri.

Factorii de agresivitate ai bolii au disparut în 7-21 zile după injecție în $88,89 \%$ cazuri.

Persistența bolii a fost confirmată în 3 cazuri $(11,11 \%)$ şi reapariția semnelor de agresivitate a RP în 2 cazuri $(7,4 \%)$, necesitând reintervenții terapeutice (fotocoagulare laser în 4 cazuri şi o nouă injecție cu bevacizumab în 1 caz).

S-a remarcat complianța bună în urmărirea evoluției bolii în primele 6 luni de viață, aceasta scăzând treptat spre vârsta de 12 luni.

RP a reapărut în 55,56\% cazuri după injecția cu bevacizumab, dar numai $18,52 \%$ au dezvoltat forma severă, care a necesitat reintervenție terapeutică.

Concluzii. Terapia RP severe din zona I prin injecție intravitreană cu bevacizumab s-a dovedit eficientă, permițând reluarea vascularizării retinei spre periferia acesteia.

Numărul mic de cazuri studiate nu a permis evaluarea unor posibile complicații locale sau sistemice pe termen lung.

Sunt necesare studii ample pentru a aprecia dacă terapia anti-VEGF prin injecție intravitreană poate afecta dezvoltarea normală a organismului prematurului. 


\section{Anti-VEGF therapy in prematurity retinopathy}

Objective. Presenting the VEGF role in the pathogenesis of retinopathy of prematurity (ROP) and anti-VEGF therapy by intravitreal injection with bevacizumab(Avastin) in severe ROP in zone I (aggressive posterior ROP, AP-ROP).

Methods. Study of 27 preterm newborns with severe ROP in zone I (AP- ROP), with birth date between November 2010 and August 2013, treated with intravitreal injection with bevacizumab, which were assessed concerning birth weight (BW) and gestational age (GA), risk factors, evolution of cases at 3, 6, 9 and 12 months postnatal age, the need for reintervention and possible complications post-treatment.

Results. The preterm newborns with AP-ROP had very low birth weights (BW $\leq 1.000 \mathrm{~g}$ in $49.15 \%$ cases) and gestational ages (GA $\leq 28$ weeks in $59.26 \%$ cases).

Risk factors present in these AP-ROP cases were: oxygenotherapy with $\mathrm{FiO} 2 \geq 40 \%$ in $96.3 \%$ cases, anemia in $74.07 \%$ cases, blood transfusion in $66,67 \%$ cases, mechanical ventilation in $59.26 \%$ cases, sepsis in $22.22 \%$ cases.

The intravitreal injection with bevacizumab was performed between 33 and 35 weeks postmenstrual age in $62.96 \%$ of the cases.

The characteristic factors of aggressiveness of the disease disappeared in 7-21 days after intravitreal injection in $88.89 \%$ cases.

The persistance of ROP was confirmed in 3 cases (11.11\%) and the recurrence of aggressive signs of the disease were recorded in 2 cases (7.4\%), which were treated with laser photocoagulation in 4 cases and a new injection with bevacizumab in 1 case.

The compliance to follow-up exams was good in the first 6 months of life, but this declined in the next 6 months.

The ROP reappeared in $55.56 \%$ cases after intravitreal injection with bevacizumab, but only in $18.52 \%$ cases the gravity of the disease required retreatment.

Conclusions. The intravitreal injection with bevacizumab for severe RP in zone I is an efficient therapy, allowing the resumption of retinal vascularisation toward the periphery.

The small number of patients from this study didn't permit the assessment of possible local and systemic long term complications of anti-VEGF treatment.

More extensive research is needed to find out if antiVEGF therapy with intravitreal injection with bevacizumab can affect the normal development of premature organism.

\section{COMPLICAṬII LA DISTANȚĂ ALE RETINOPATIEI DE PREMATURITATE LA PREMATURII TRATATII ÎN PERIOADA 2002-2010 ÎN IOMC „A. RUSESCU“}

Dr. Tatiana Ciomârtan"1,2, Dr. Constanța Nascutzy ${ }^{1}$, Dr. Ileana Vătavu¹, Dr. Oana Popteanu², Prof. Dr. Ioana Anca ${ }^{1,2}$, Prof. Dr. Sivia Stoicescu ${ }^{1,2}$

${ }^{1}$ IOMC „A. Rusescu“, București

¿2UMF „C. Davila“, București

Obiective. Analiza complicațiilor la distanță ale retinopatiei de prematuritate (RP) la prematurii cu forme severe de boală.

Material şi metode. Lotul de studiu a fost reprezentat de prematurii născuți în perioada 2002-2009 care au beneficiat de tratament pentru RP; am realizat o analiză descriptivă a incidenței complicațiilor la distanță şi o analiză comparativă a acestora în grupul prematurilor născuți cu greutate la naştere $(G n)<1.500 \mathrm{~g}$ vs restul lotului. Analiza statistică a fost realizată cu SPSS versiunea 20.0.

Rezultate. Au fost tratați cu laser 485 de prematuri, dintre care numai 93 au avut date complete. Pe acest lot, vârsta gestațională (VG) medie a fost de 29,8 săptămâni (91,4\% cu VG $\leq 32$ săptămâni), Gn medie a fost de $1.384 \mathrm{~g}$ $(64,5 \%$ cu Gn $<1.500 \mathrm{~g})$. Rezultatele tratamentului laser au fost similare cu cele citate în literatură, regresie la 92,5\% dintre cazuri.

Prognosticul vizual (cea mai bună acuitate vizuală corectată) a fost bun la 50/93 - vedere normală; 6/93 au avut pierdere moderată şi severă a vederii şi 3 aveau cecitate.

Principalele complicații la distanță au fost ambliopia (incidență $36,6 \%$ ), strabismul (35,5\%), viciile de refracție (miopie $54,8 \%$, hipermetropie $46,2 \%)$, nistagmusul $(5,4 \%)$ şi astigmatismul (65\%). Corelații semnificative $s$-au obținut între strabism (OR 6, $p<0,001)$ şi miopie (OR 4, $p=0,002$ ) şi ambliopie.

Ambliopia, strabismul şi miopia au avut incidență mai mare (fără semnificație statistică din cauza numărului mic de cazuri) la prematurii cu $\mathrm{G} n<1.500 \mathrm{~g}$.

Concluzii. Prematurii cu forme severe de retinopatie de prematuritate, care sunt diagnosticați şi tratați la timp, au prognostic bun - regresie la marea majoritate şi vedere normală la peste jumătate dintre cazuri. Totuşi, aceşti copii au şi complicații la distanță precum ambliopie, strabism şi vicii de refracție, care necesită urmărire atentă pe termen mediu şi lung şi tratament precoce realizat de oftalmopediatri specializați. 
Long term complications of retinopathy of prematurity in infants treated in the Institute for Mother and Child Care between 2002 and 2010

Objectives. Analysis of long term complications of retinopathy of prematurity (ROP) in infants with severe forms.

Material and methods. The study sample included infants born between 2002 and 2009 that required treatment for retinopathy of prematurity (ROP); we performed a descriptive analysis of the incidence of long term complications and a comparative analysis of these in infants with birth weight $(B W)<1,500 \mathrm{~g}$ vs the rest of the sample. Statistical analysis was performed with SPSS vs 20.0 .

Results. 485 infants underwent laser treatment, only 93 from them had complete data. On this sample, mean gestational age (GA) was 29.8 weeks (91.4\% had GA $\leq 32$ weeks, mean BW was 1,384 g (64.5\% had BW $<1,500 \mathrm{~g})$. The results of laser treatment were similar with those reported in the literature, regression in $92.5 \%$ of cases.

Visual outcome (best corrected visual acuity) was good in 50/93 - normal vision; 6/93 had moderate and severe visual loss and 3 were blind.

Main long term complications were amblyopia (incidence $36.6 \%$ ), strabismus (35.5\%), refractive errors (myopia $54.8 \%$, hypermetropia $46.2 \%)$, nistagmus (5.4\%) and astigmatism (65\%). Significant correlations were observed between strabismus (OR 6, p < 0.001) and myopia (OR 4, $p=0.002$ ) and amblyiopia.

Amblyopia, strabismus and myopia had a higher incidence (though not reaching statistical significance because of the small sample) in infants with $\mathrm{BW}<1,500 \mathrm{~g}$.

Conclusions. Preemies with severe ROP that benefit from early diagnosis and treatment have good outcomes regression in most cases and normal vision in over half of them. Nevertheless, these infants have long term complications such as amblyopia, strabismus and refractive errors that require medium and long term follow-up and early treatment performed by specialized pediatric ophthalmologists.

\section{PREVENIREA RISCULUI DE SEPARARE/ ABANDON DE CĂTRE FAMILIE AL COPILULUI ÎN MATERNITATE}

As. social Linca Miana

IOMC „Alfred Rusescu“, București

- Activitatea cabinetului de asistență socială din cadrul departamentului de obstetrică-ginecologie "Gh. Polizu“, Bucureşti

- Situația centralizată a cazurilor aflate în evidența cabinetului de asistență socială (analiză cantitativă)
- Statistica la nivel național privind copiii părăsiți în maternitate

- Concluzii generale

Risk prevention of child abandonment/separation from family in maternity

- Activity in the office of social department of Obstetrics-Gynecology „Gh. Polizu“, Bucharest

- The centralized situation recorded at the office of social work (quantitative analysis)

- National statistics about the children left in maternity

- General conclusions

\section{ANOMALIILE CROMOZOMIALE ÎN PRACTICA MEDICALĂ}

Vasilica Plăiașu, Diana Ochiană, Gabriela Moței IOMC „Alfred Rusescu“, București

Anomaliile cromozomiale determină o gamă largă de boli asociate cu defecte la naştere şi boli congenitale. Unele dintre acestea provoacă deces al embrionului sau fătului înainte de naştere. Anomaliile cromozomiale variază din punct de vedere fenotipic şi sunt frecvent asociate cu anomalii congenitale multiple, retard mental şi retard de creştere. În Europa, frecvența anomaliilor cromozomiale a fost estimată la 15\% dintre anomaliile congenitale majore diagnosticate înainte de vârsta de 1 an.

Anomaliile cromozomiale pot afecta orice cromozom, inclusiv cromozomii sexuali şi pot afecta atât numărul, cât şi structura acestora. De asemenea, pot fi familiale sau de novo.

Evaluarea citogenetică poate fi realizată în timpul sarcinii sau după naştere. Există numeroase posibilități pentru a detecta aceste condiții. Cu descoperirile tehnologice recente, noi metode înalt sensibile, complementare s-au dezvoltat, crescând rata de detecție a anomaliilor cromozomiale. Fiecare metodă are propriile avantaje şi limitări şi ar trebui aplicată selectiv, după o consiliere genetică specifică.

În lucrarea de față datele in-house privind rezultatele testelor citogenetice din partea de sud a României au fost analizate şi sunt prezentate concluzii. Pacienții au prezentat aneuploidii, deleții şi duplicații, translocații neechilibrate, tetraploidie, cromozomi marker şi anomalii de cromozomi sexuali.

Tabloul clinic complet rezultat dintr-o abordare multidisciplinară, istoricul familial cu înregistrarea unui arbore genealogic complet reprezintă principalele criterii de selecție în acord cu principalele ghiduri generale de analiză citogenetică. Consilierea genetică are un rol integrativ pentru toate aceste informații, în vederea stabilirii diagnosticu- 
lui final, managementul cazului şi familiei acestuia, inclusiv pentru viitorul reproductiv.

Notă: Acest studiu a fost finanțat prin Programul Național VI, obiectiv 3.3 al Ministerului Sănătații şi grantul PNII-PT-PCCA-2013-4-2240

\section{Chromosomal abnormalities in clinical practice}

Chromosome abnormalities cause a wide range of disorders associated with birth defects and congenital diseases. Some of them cause the death of the embryo or fetus before birth. Chromosomal anomalies are known to vary widely from the phenotypically viewpoint and are frequently associated with multiple congenital anomalies, mental retardation and failure to thrive. In Europe, the frequency of chromosomal abnormalities has been estimated at $15 \%$ of the major congenital anomalies diagnosed before the age of 1 year. Chromosomal abnormalities can affect any chromosome, including the sex chromosomes and can affect their number or structure. Also, they can be familial or de novo.

Cytogenetic evaluation can be performed during pregnancy or after birth. There are numerous possibilities to detect these conditions. With recent technological progress, new highly sensitive, complementary methods have been developed, increasing the rate of detection of chromosomal abnormalities. Each method has its own advantages and limitations and should be cautiously applied, after proper genetic counseling.

In-house data of cytogenetic testing results from the south part of Romania was analyzed and the summary data are presented. Our patients were defined as cases with aneuploidy, deletions and duplications, unbalanced translocation, tetraploidy, marker chromosomes, and sex chromosome anomalies.

A complete clinical picture resulting from a multidisciplinary approach and family history with an accurate pedigree are the main selection criteria according to general guidelines for cytogenetic testing. Genetic counseling has the integrating role for all these information, for final diagnosis, management of the case and the family, including reproductive future.

Acknowledgments: This work was supported by Objective 3.3 of Romanian Ministry Health Program VI and by PN-II-PT-PCCA-2013-4-2240 grant

\section{MANAGEMENTUL MODERN ÎN UNELE BOLI GENETICE}

Prof. Dr. Matei Dumitru

IOMC „Alfred Rusescu“, București

După descoperirea genomului uman studiile din domeniul geneticii au dus la determinarea etiologiei genetice a multor boli şi s-a trecut la dezvoltarea metodelor de diagnostic precoce, a studierii posibilității intervenției terapeutice şi a posibilității prevenției.

Consilierea genetică presupune înțelegerea riscului şi explicarea lui genitorilor pentru a putea lua o decizie informată cu următoarele opțiuni: asumarea riscului, efectuare de investigații genetice intrapartum, cunoaşterea şi acceptarea posibilități lor de tratament, supraviețuire, calitatea vieții. Diagnosticul precoce presupune efectuare de diagnostic preconceptual, prenatal sau screening neonatal. În diagnosticul prenatal sunt folosite metode non-invazive sau metode invazive. Screeningul neonatal se poate realiza actual pentru 64 de boli genetice, în România - pe scară națională doar pentru fenilcetonurie, hipotiroidism congenital, galactozemie.

Tratamentul în bolile genetice în acest moment nu este disponibil pentru marea majoritate a bolilor şi este adesea simptomatic sau substitutiv.

În IOMC în cadrul derulării Programului Național de Sănătate a Femeii şi Copilului se efectuează acest tip de intervenție pentru: fenilcetonurie, hipotiroidism, fibroză chistică, talasemie majoră. În cadrul intervenției privind pacientul cu fibroză chistică, tratamentul este complex şi implică intervenție nutrițională (terapie enzimatică, suplimentare vitaminică şi nutrițională), tratamentul afectării respiratorii şi multiorganice, fizioterapie.

Se promovează medicina personalizată adică adaptarea regimului terapeutic la nevoile medicale ale pacientului şi în acelaşi timp a programului social pentru a asigura integrarea în societate.

Prognosticul pe termen lung în bolile genetice este dat de: diagnosticul precoce, dispensarizare şi controale frecvente pentru evidențierea complicațiilor şi intervenției terapeutice.

Pentru îmbunătățirea acestui proces se recomandă introducerea screeningului neonatal național pentru mai multe boli genetice, dezvoltarea unor retele specializate de monitorizarea bolilor genetice, înființarea/actualizarea unui Registru Națioanal Boli Genetice, participarea la studii clinice de dezvoltare a terapiei genice sau a noi tratamente.

\section{Modern management in some genetic disorders}

After the discovery of the human genome, genetic field studies revealed genetic etiology for many diseases, which 
led to early diagnosis methods, studies on therapeutic interventions and the possibility of prevention.

Genetic counseling implies understanding the risks and explaining them to genitors in order to take an informed decision, choosing to take the risk, to have intrapartum genetic investigations, knowing and accepting treatment possibilities, survival and quality of life. Early diagnosis involves: preconception or prenatal diagnosis or neonatal screening. In prenatal diagnosis noninvasive or invasive methods may be used. Neonatal screening is available for 64 genetic disorders. In Romania we use neonatal screening on a national scale only for phenylketonuria, congenital hypothyroidism and galactosemia.

For the majority of the genetic diseases, etiologic treatment is not available. It's often used symptomatic or substitutive treatment.

In the Mother and Child Care Institute we are running the National Programme for Mother and Child Health which involves this type of intervention for: phenylketonuria, hypothyroidism, cystic fibrosis, thalassemia major. Regarding the cystic fibrosis patient, the treatment is complex and involves nutritional intervention (PERT therapy, vitamins and nutritional supplements), pulmonary and multiorgan affect treatment and physiotherapy. We are promoting personalised medicine, meaning adapting the therapeutic regime to the medical and social needs of the patients in order to ensure his integration in the society.

The long-term prognosis in genetic disorders is given by: early diagnosis, frequent assessments to reveal complications and therapeutic intervention.

In order to improve this process it is recommended to introduce neonatal screening on a national scale for more genetic disorders, to develop specialized networks for monitoring genetic disorders, to found/update a National Registry for Genetic disorders, to participate in clinical trials for developing genic therapies or new treatments.

\section{ACTUALITĂṬI ÎN IMUNODEFICIENȚELE PRIMITIVE (PID)}

Prof. Dr. Ioan Gherghina, Prof. Dr. Dumitru Matei, Dr. Alexis Virgil Cochino, Dr. Mirela Covăcescu, Dr. Vasilica Plăiașu

IOMC „Alfred Rusecu“, București

Lucrarea cuprinde datele actuale cu privire la diagnosticul genetic până la nivel molecular şi totodată actualitățile în tratamentul PID.

Metoda de lucru. Prezentarea sintetică sub formă de tabel a cazurilor clinice cu copii diagnosticați cu PID în ultimii 10 ani în IOMC „A. Rusescu“ şi prezentarea în detaliu a două cazuri clinice, informare din literatura medicală şi din lucrările Congresului al 16-lea al Societății Europene pentru
Imunodeficiențele Primitive din 29.10.2014 - 01.11.2014, Praga, Republica Cehă.

Rezultatele obținute. Cazurile clinice prezentate au ilustrat importanța şi necesitatea investigațiilor imunologice şi genetice pentru diagnosticul final în PID şi valoarea tratamentului cu antibiotice, IG i.v. pentru infecțiile recurente, TMO şi HSCT.

Observația nr. 1. O fetiță în vârstă de 3 ani şi 6 luni, care a prezentat frecvente infecții respiratorii. Investigația imunologică a arătat un sindrom hiper IgM cu scădere IgA şi IgG, IgM $366 \mathrm{mg} / \mathrm{dl}(40+140)$, IgG sub $2 \mathrm{mgr} / \mathrm{dl}$ (350- 1.000 $\mathrm{mg} / \mathrm{dl})$, IgA sub $4 \mathrm{mg} / \mathrm{dl}$ (19-220).

Diagnosticul molecular a fost efectuat în laboratorul Fundației Jeffrey Modell din Debrețin, Ungaria şi acesta a arătat că pacientul este homozigot pentru mutația C.441C $>$ AC la nivel pC 147 x pe gena AICDA (exon 4). Astfel s-a precizat diagnosticul de sindrom Hiper IgM tip 2.

Observația nr. 2. Este un băiat în vârstă de 6 ani, cu diagnosticul de sindrom Klinefelter care a prezentat şi frecvente infecții respiratorii. Imunograma a evidențiat o hipogamaglobulinemie: $\operatorname{lgM}: 0,27 \mathrm{~g} / \mathrm{l}, \operatorname{lgG}: 2,5 \mathrm{~g} / \mathrm{l}$; IgA: 0,03 g/l. Imunofenotiparea limfocitelor arată o scădere marcată a limfocitelor $C D / 9+: 0,5 \%$.

Tratament substitutiv cu IgG i.v. 0,4 g/kgcorp la fiecare 4 săptămâni. Examenul genetic efectuat într-un laborator din Brno, Republica Cehă, a arătat mutația p.His 362 Arg pe gena BTK. Mama era purtătoare pentru această mutație: diagnostic final: XLA Bruton cu sindrom Klinefelter - este primul caz cu asocierea celor două boli din literatura medicală.

Se are în vedere şi tratamentul endocrin.

Elementul cel mai important în genetica infecțiilor la copil şi adult este în prezent utilizarea metodei Next Generation Sequenceing (studiul secvențial de nouă generație NGS).

Această metodă a permis identificarea unor noi boli genetice PID exprimate clinic prin infecții, sindroame alergice, boli autoimune, neoplazii şi boli autoinflamatorii.

În tratamentul genetic s-a renunțat la retrovirus ca vehicul, din cauza riscului oncogen.

\section{Concluzii:}

1. Cazurile prezentate şi datele din literatura medicală au subliniat importanța diagnosticului genetic pâna la nivel molecular pentru realizarea diagnosticului final în PID.

2. În unele cazuri este necesară aplicarea de urgență a tratamentului în PID (substitutiv etc.) bazat pe diagnosticul imunologic, înaintea diagnosticului molecular final.

\section{News in primitive immunodeficiency}

The paper includes current data on molecular genetics diagnosis and the treatment of PID.

Working method. The paper includes a synthetic presentation of clinical cases of children diagnosed with PID in 
the past 10 years in IOMC „A. Rusescu“ and a detailed presentation of two clinical cases in the perspective of the new information from the medical literature and from the papers of the-16th Congress of the European Society of Primitive immunodeficiency 29.10.2014 - 11.01.2014, Prague, Czech Republic.

The results. The clinical cases presented have shown the importance and necessity of immunological and genetic investigations for final diagnosis in PID and the value of antibiotic therapy, IVIg recurrent infections, TMO and HSCT.

Note no. 1. A 3 years and 6 months old girl, who presented frequent respiratory infections. Immunological investigation revealed a hyper IgM syndrome with decrease in IgA and IgG, IgM $366 \mathrm{mg} / \mathrm{dl}(40+140) \operatorname{lgG}$ to $2 \mathrm{mgr} / \mathrm{dl}$ (350-1,000 mg/dl), IgA as $4 \mathrm{mg} / \mathrm{dl}$ (19-220).

Molecular diagnosis was performed in the laboratory of Jeffrey Modell Foundation in Debrecen, Hungary and it showed that the patient is homozygous for the mutation C. $441 C>A C$ at $147 \mathrm{pC} x$ on AICD gene (exon 4). Thus stated Hyper IgM syndrome diagnosed type 2 .

Note no. 2. Is it a boy aged 6 years, diagnosed with Klinefelter syndrome who presented also frequent respiratory infections. The Immunogram revealed a hypogammaglobulinemia: IgM: $0.27 \mathrm{~g} / \mathrm{l}$, IgG: $2.5 \mathrm{~g} / \mathrm{l}$; IgA: $0.03 \mathrm{~g} / \mathrm{l} . \mathrm{Im}$ munophenotyping lymphocytes show a marked decrease in lymphocyte $\mathrm{CD} / 9+0.5 \%$. Iv IgG substitution treatment $0.4 \mathrm{~g} / \mathrm{kg}$ every 4 weeks. Genetic examination performed in a laboratory in Brno, Czech Republic, showed 362 Arg mutation $p$.His the BTK gene. The mother was a carrier for this mutation: final diagnosis: XLA Bruton Klinefelter syndrome - is the first case with the combination of the two diseases in the medical literature.

The most important element in genetics of infections in children and adults is currently the use of the method Next Generation sequencing. This method allowed the identification of new genetic diseases PID clinically expressed by infections, allergic syndromes, autoimmune diseases, cancers and auto-inflammatory diseases.

In genetic therapy there has been quitted the retrovirus as vehicle because of its risk of cancer development.

\section{Conclusions:}

1. The presented cases and the data from the medical literature have emphasized the importance of genetic diagnosis at the molecular level up to achieve the final diagnosis in PID.

2. In some cases urgent application in PID treatment (substitution etc.) is needed, based on immunological diagnosis before the final molecular diagnosis.

\section{TESTAREA SENSIBILITĂȚII LA SAPROPTERINĂ A COPIILOR CU HIPERFENILALANINEMIE - PREZENTTA UNEI NOI ABORDĂRI TERAPEUTICE}

\section{Dr. Florentina Moldovan \\ IOMC „Alfred Rusescu“, București}

Studiul clinic privind răspunsul copiilor cu fenilcetonurie la testul de încărcare cu sapropterina s-a efectuat pe un lot de 19 copii cu vârsta mai mare de 4 ani, aflați în tratament dietetic specific. Copiii din studiu au primit tratament $\mathrm{cu}$ sapropterină în doză zilnică unică de $20 \mathrm{mg} / \mathrm{kg}$ corp timp de şapte zile, fără modificări ale dietei în acest interval. Înainte de începerea tratamentului cât şi după cele 7 zile de tratament s-a efectuat la fiecare copil dozarea fenilalaninei plasmatice.

Responsivitatea la tratament a fost evaluată prin compararea nivelului plasmatic al fenilalaninei înainte şi după tratament.

S-au considerat responsivi la sapropterină copiii care după testare au prezentat o scădere a nivelului plasmatic al fenilalaninei de cel puțin 30\%. Din analiza rezultatelor s-a constatat că 9 din cei 19 copii incluşi în studiu au fost responsivi la testare.

În prezent toți copiii responsivi la sapropterină beneficiază de tratament medicamentos gratuit cu sapropterină pe termen lung, în cadrul unui program național de sănătate. Scopul tratamentului este creşterea toleranței la fenilalanină şi relaxarea restricțiilor dietetice. Sapropterina este în prezent singurul medicament aprobat în România pentru tratamentul pacienților cu fenilcetonurie.

\section{Sapropterin susceptibility testing of children with hyperphenylalaninemia - new therapeutic approach}

A clinical survey concerning the response of PKU affected children to the loading test with sapropterine has been carried out on a sample group of 19 children over 4 years old and receiving the specific restricted diet. One daily single dose of $20 \mathrm{mg} / \mathrm{kg}$ bw of sapropterine was administrated to each child for 7 days, without modifications in the diet. The plasmatic level of phenylalanine was determined before and after the treatment.

The responsiveness to sapropterine was evaluated by comparing the levels of blood phenylalanine before and after treatment. A decrease of minimum $30 \%$ of blood level of phenylalanine was defined as a positive response to the test.

The analysis of results revealed that 9 from the total of 19 children included in the survey were responsive. Currently all children with PKU that prove responsive to the 
sapropterine loading test receive the treatment on the long term within a national health program.

The goal of the medical treatment is to increase PHE tolerance and relax the diet restrictions. Sapropterine is today the only medical treatment of PKU affected patients, that is approved in Romania.

\section{REGISTRU PENTRU FENILCETONURIE ŞI HIPOTIROIDIE}

Michaela Nanu ${ }^{1}$, Vasile Despan ${ }^{1}$, Traian Zvirid ${ }^{2}$

IIOMC „Alfred Rusescu“, București

${ }^{2}$ CAMSCAPE

Obiectiv. Lucrarea îşi propune prezentarea sistemului informatic utilizat in screeningul neonatal PKU şi hipotiroidie.

Metodă. Sistemul informatic a fost elaborat în cadrul unui proiect finanțat cu fonduri structurale europene (CAPAD). Acesta este format din două componente şi anume o bază de date a copiilor incluşi în screningul neonatal şi un registru al copiilor diagnosticați cu afecțiunile anterior menționate.

Sistemul este structurat pe 4 niveluri de acces online şi anume maternitate, direcția de sănătate publică, medic curant, administrator.

Fiecare nivel are acces numai la proprii copiii înregistrați cu excepția administratorului care vizualizează toți copiii introduşi în sistem. În acest fel a fost construită o bază de date pentru fiecare nivel.

Sistemul generează rapoarte care permit o prelucrare statistică în funcție de itemii selectionați a fi prelucrați.

Rezultate. în prezent raportează în sistemul informatic 29 de județe începând cu anul 2012.

În registru sunt în prezent incluşi 248.983 pe copii din care 794 au valori modificate la screeningul neonatal pentru hipotiroidie şi 95 pentru fenilcetonurie.

Concluzii. Sistemul informatic este un instrument util în evaluarea implementării programului de screening PKU şi hipotiroidie, în monitorizarea bolnavului dar şi în elaborarea unor studii în domeniu.

Sistemul informatic este perfectibil şi permite adaptarea pentru utilizarea sa şi în alte afecțiuni.

Cuvinte cheie: screening PKU, hipotiroidie, registru, România

\section{Register for phenylketonuria and hypothyroidism}

Objective. This paper aims to present the system used in neonatal screening PKU and hypothyroidism.

Method. The computer system was developed under a project financed by EU structural funds (CAPAD). It consists of two components, namely a database of children included in the neonatal screening and a registry of the children diagnosed with the previous mentioned disorders.

The system is divided into five online access levels, namely: maternity, local health authority, physician, administrator.

Each level has access only to its registered children excepting the administrator who visualizes all the children entered into the system. Thus a database for each level was built. The system generates reports that allow statistical processing depending on the items selected to be processed.

Results. Currently, in the computer system since 2012, 29 counties are reporting 248,983 children who underwent screening were included, 794 children with positive results for hypothyroidism and 95 children with PKU are monitored.

Conclusions. The computer system is a useful tool in assessing the implementation of the PKU and hypothyroidism screening program, in monitoring the patient but also in the development of studies.

The computer system is improvable and allows adaptation for use in other diseases.

Keywords: screening PKU, hypothyroidism, register,

Romania

\section{DETERMINISMUL GENETIC AL UNOR BOLI DIGESTIVE LA COPIL - APLICABILITATE CLINICĂ}

Dr. Alina Popp

IOMC „Alfred Rusescu“, București

Studiile genomice extinse au permis identificarea tot mai multor determinanți genetici într-o serie de boli digestive.

Deşi complexitatea interacțiunilor genom-proteom şi expresia lor fenotipică este încă incomplet descrisă, testarea genetică a depăşit pentru unele afecțiuni digestive la copil abstractul implicațiilor patogenice devenind un instrument aplicabil în clinică. Ghidurile de conduită ale unor boli digestive includ în prezent testările genetice ca alternative noninvazive de investigație, elemente de prognostic şi determinanți ai sfatului genetic.

Testarea genetică în practica clinică pediatrică a permis în ultima decadă reformularea multora dintre diagnosticele bazate pe datele clinice şi imunologice clasice, conducând la reconsiderarea abordărilor terapeutice şi de monitorizare a acestor bolnavi. Prototipul acestui tip de scenariu clinic îl reprezintă boala celiacă. Utilizarea genotipării pentru această boală în cazuistică IOMC a condus la modificarea radicală a abordării medicale pentru unii dintre pacienți cu 
afectare digestivă cronică, iar pentru alții a permis stabilirea unui plan de monitorizare eficient.

Paradoxal, deşi testările genetice sunt relativ greu accesibile şi costisitoare, recent se observă tendința utilizării lor chiar şi în cazuri în care informația adusă în urma testării nu implică un alt tip de abordare clinică.

Prototipul acestui tip de scenariu clinic îl reprezintă intoleranța primară la lactoză pentru care tot mai multe testări genetice se realizează în afara indicației medicale.

Stabilirea unor recomandări pentru utilizarea rațională a studiului genetic în unele boli cronice constitue o necesitate practică.

\section{Genetic determinism of digestive diseases in children - clinical applicability}

Extensive genomic studies have allowed the identification of more and more genetic determinants in a number of digestive diseases. Although genome-proteome complexity of interactions and their phenotypic expression is still incompletely described, genetic testing has exceeded for some child digestive diseases the abstract of pathogenic implications, becoming an instrument applicable in the clinic.

Guidelines for the conduct of digestive diseases include genetic tests as currently noninvasive alternatives of investigation, prognostic factors and determinants of genetic counseling.

Genetic testing in pediatric clinical practice has allowed in the last decade reformulating many of the diagnoses based on the classical clinical and immunological data, leading to reconsideration of therapeutic approaches and monitoring of these patients. The prototype of such clinical scenario is the celiac disease. Use of this disease genotype in the IOMC casuistry led to radical change of the medical approach for some patients with severe chronic digestive and for others allowed establishing an effective monitoring plan.

Paradoxically though genetic tests are relatively inaccessible and expensive, recently there is a tendency to use them even in cases where the information obtained from testing does not involve another type of clinical approach. The prototype of such clinical scenario is the primary lactose intolerance for which more and more genetic tests are made outside medical indication.

Establishing recommendations for rational use of genetic study in some chronic diseases is a practical necessity.

\section{MODIFICĂRI HEMATOLOGICE ÎN BOLI GENETICE METABOLICE (GM 1 - GANGLIOSIDOSIS)}

Dr. Anca Ghiță, As. pr. Mariana Buia,

As. pr. Gianina Parapancea, As. pr. Ștefania Șerban IOMC „Alfred Rusescu“, București

Gangliozidoza este o boală genetică metabolică rară (autozomal recesivă), neurodegenerativă (cuprinde trei tipuri în funcție de vârsta debutului şi gradul de implicare viscerală) datorată unui deficit de GM1 - gangliosid-betagalactozidaza în lizozomală ce duce la acumularea de substrat nemetabolizat (GM 1 gangliosid) în ficat, splină, măduvă osoasă şi sistemul nervos central CNS.

Analiza moleculară a demonstrat existența unei varietăți de mutații în gena gangliosid-beta-galactozidazei de pe cromozomul 3p21.33.

În spitalul nostru au fost internați cinci copii, cu tipul 1 de gangliozidoză, cu vârsta la debut cuprinsă între 0 şi 7 luni având deformări faciale, pată cireşie maculară la examenul fundului de ochi, hipotonie, hepatosplenomegalie, retard şi numeroase limfocite cu vacuole în citoplasma pe frotiul din sânge periferic, precum şi celulele spumoase pe frotiul din aspiratul medular. Diagnosticul a fost confirmat prin dozarea activității beta-galactozidazei din lizozomii limfocitelor din sângele periferic şi din fibroblaşti.

Concluzii:

1) Gangliozidoza GM1 este o boală genetică metabolică rară, probabil subdiagnosticată.

2) Suspiciunea diagnosticului de gangliozidoză tip 1 presupune existența pe FSP a numeroase vacuole în limfocite, eventual şi în polimorfonucleare neutrofile şi eozinofile (FSP fiind uşor de efectuat, rapid şi ieftin).

3) Confirmarea diagnosticului se face pe baza unor teste biochimice şi genetice costisitoare care necesită timp îndelungat.

4) Diagnosticarea gangliozidozei tip 1

- are mai puțină valoare pentru pacientul în sine (neexistând un tratament curativ);

- foarte importantă pentru părinții copilului bolnav, în vederea viitoarelor sarcini (fiind posibil diagnosticul precoce prenatal) pentru a preveni apariția unui nou caz).

5) Este important să avem în vedere bolile metabolice de tezaurizare (in special gangliozidoza) şi să efectuăm un frotiu din sânge periferic dacă un pacient prezintă malformații faciale, osoase, tulburări neurologice (hipotonie sau regres neuromotor) şi organomegalie (hepato-splenomegalie). 


\section{Hematological modifications in metabolic genetic diseases}

Gangliosidosis is a rare inherited (autosomal recessive) lysosomal storage disease, neurodegenerativ (three types based on age at onset and degree of visceral involvement) owing to a deficiency of GM 1-ganglioside-beta-galactosidase in the lysosmes resulted in accumulation of its substrate (GM 1 ganglioside) in liver, spleen, bone marrow and central nervous system CNS. Molecular analysis have demonstrated a variety of mutations in the gene of gangliosidbeta-galactosidase on the chromosome 3p21.33.

We had five children in our hospital with gangliosidoses types I with the age at onset from birth to 7 months, with facial deformities, cherry-red macula, hypotonia, hepatosplenomegaly, retardation, and vacuolation of peripheral lymphocytes and foamy cells in bone marrow aspirates. The diagnosis was confirmed by assay of plasma leukocytes, or fibroblasts beta-galactosidase activity.

\section{Conclusions}

1. Because lysosomal storage disorders are recognized by the presence of vacuolated lymphocytes in peripheral blood and foamy storage cells in bone marrow aspirates, peripheral blood film is necesary in any case of children with skeletal or facial deformities, hypotonia, and hepatosplenomegaly. The blood film is a very easy and rapid investigation.

2. The early diagnosis of gangliosidosis is important for the child with gangliosidosis but there are no cures for lysosomal storage diseases and is more important for the parents because prenatal diagnosis is possible for future pregnancies - to prevent storage disease.

\section{CAUZĂ RARĂ DE SINDROM FEBRIL PRELUNGIT LA SUGAR}

Oana Farkas, Mirela Covăcescu, Carmen Băjenaru, Irina Coltoiu, Vasilica Plăiașu

IOMC „Alfred Rusescu“, București

Introducere. Sindromul febril prelungit la sugar poate crea dificultăți de diagnostic, mai ales dacă nu există manifestări clinice asociate.

Material şi metodă. Prezentăm cazul unui sugar de sex masculin în vârstă de 5 luni şi jumătate, transferat în IOMC "Alfred Rusescu", Bucureşti pentru investigarea unor episoade repetate de febră aparent fără focar.

Rezultate şi discuții. Anamneza, particularitățile descoperite la examenul clinic, investigațiile efectuate şi suspiciunea ridicată la consulturile interdisciplinare (dermatologic şi genetic) au dus la diagnosticarea unei cauze rare, cu transmitere genetică de sindrom febril prelungit la sugar. Diagnosticul genetic nu a putut fi însă efectuat. Cu toate acestea, modificările fenotipice caracteristice observate la examenul clinic, anamneza care a relevat existența unor manifestări izolate şi la sora sugarului, precum şi investigațiile efectuate, au ridicat suspiciunea de displazie anhidrotică ectodermală, confirmată atât de consultul dermatologic, cât şi de consultul genetic efectuat.

În concluzie, chiar dacă testarea genetică nu a fost accesibilă, un rol important în precizarea diagnosticului în acest caz a revenit anamnezei, examenului clinic şi consulturilor interdisciplinare efectuate.

\section{A rare cause of prolonged fever syndrome}

Introduction. A baby with prolonged fever syndrome may be difficult to diagnose, especially if there are no clinical manifestations associated.

Material and methods. We present the case of a 5 1/2-months baby boy, transfered in IOMC "Alfred Rusescu“ Bucuresti for the investigation of recurrent fever episodes apparently of unknown origin.

Results and discussion. History, particularities revealed by the clinical examination, results of the investigations and suspicions raised by the dermatologic and genetic consults led to the diagnosis of a rare genetically transmitted cause of a prolonged febrile syndrome. Unfortunately the genetic diagnosis couldn't be obtained. Nevertheless, typical phenotypic changes observed at the clinical examination, history that revealed the presence of isolated manifestations in baby's older sister, as well as the performed investigations raised the suspicion of hypohidrotic ectodermal dysplasia, confirmed by the dermatologic and genetic consults.

In conclusion, even though genetical testing wasn't possible, history, clinical findings and interdisciplinary consults had an important part in stating the diagnosis in this case.

\section{SARCOIDOZA CU DEBUT PRECOCE - PREZENTARE DE CAZ}

\author{
Dr. Laura Dinică, Dr. Adela Rădulescu, \\ Dr. Carmen Navrea
}

IOMC „Alfred Rusescu“, București

Sarcoidoza este o boală sistemică granulomatoasă rar întâlnită la copilul mic, cu etiologie necunoscută, caracterizată de prezența de granuloame noncazeoase în organele afectate. Cel mai frecvent acestea sunt: plămânii, ganglionii limfatici, pielea, ochii, splina, ficatul. La copil, sarcoidoza poate îmbrăca două forme. Copiii mai mari de 4 ani prezintă o boală multisistemică similară cu cea a adultului, predominând afectarea pulmonară şi ganglionară în contrast cu debutul precoce ( $<4$ ani) în care tabloul clinic este caracterizat de triada: erupție cutanată, uveită şi artrită. 
Diagnosticul bolii este cel mai adesea unul de excludere. Prezentarea de față cuprinde un caz atipic al unei fetițe de 3 ani şi 9 luni cu un istoric marcat de numeroase pusee febrile însoțite de frison, debutate în urmă cu un an anterior prezentării în clinica noastră. Investigațiile extensive conduse în străinătate exclud o multitudine de boli imunologice, infecțioase şi tumorale însă, fără a reuşi să stabilească diagnostiul de certitudine.

După 4 luni de evoluție a bolii, presărate cu multiple antibioticoterapii fără eficiență terapeutică, un consult reumatologic ridică suspiciunea de boală sistemică şi se inițiază un tratament empiric cu Prednison, pe care copilul l-a urmat 5 luni cu o evoluție favorabilă. La 1 lună după întreruperea tratamentului reapar puseele febrile şi creşterea în volum a abdomenului (hepatosplenomegalie), motiv pentru care se prezintă în clinica noastră.

Se reiau o parte din investigații şi ridicându-se suspiciunea de boală granulomatoasă, se dozează ACE şi se prelevează biopsii (splenică şi hepatică), care stabilesc diagnosticul de sarcoidoză şi permit reluarea terapiei orale cu corticosteroizi cu remiterea simptomatologiei.

\section{Early-onset childhood sarcoidosis: a case report}

Sarcoidosis is a granulomatous systemic disease rarely seen in young children, of unknown etiology, characterized by the presence of noncaseating granulomas in affected organs. Most often the affected organs are: lungs, lymph nodes, skin, eyes, spleen, liver. In children, sarcoidosis can take two forms. Children over 4 years old have a multisystemic disease as seen on adults, predominantly affecting the lungs and lymph nodes in contrast with early onset (under 4 years old) in which the clinical picture is characterized by the following triad: rash, uveitis and artritis.

The diagnosis of the disease is often one of exclusion. This case report contains an atypical case of a $3 \mathrm{y}$. and $9 \mathrm{~m}$. old girl with a history marked by numerous bouts of fever with chills, all of these debuting a year ago prior to the presentation in our clinic. Extensive investigations conducted abroad excluded a variety of immunological diseases, infectious and tumor but without being able to establish a certain diagnosis.

After 4 months of progressing disease, sprinkled with multiple inefficient antibiotic therapies, a rheumatology consultation raises the suspicion of systemic disease and decides to initiate empiric treatment with prednisone, which the patient followed for five months with a favorable outcome. One month after discontinuation, fever episodes reappear and the abdomen increased in volume (hepatosplenomegaly), which is why the child adresses our clinic.

Some of the investigations were repeated and, taking in consideration the suspicion of granulomatous disease, ECA was dosed and biopsies (spleen and liver) were performed which confirmed the diagnosis of sarcoidosis and allowed resumption of oral corticosteroid therapy with remission of symptoms.

\section{ERUPTIIE ACRODERMATITIS ENTEROPATHICA-LIKE: PREZENTARE DE CAZ}

Dr. Alexandra Colțoiu, Dr. Rodica Crețu,

Dr. Florin Brezan, Dr. lustina Stan,

Dr.Vasilica Plăiașu

IOMC „Alfred Rusescu“, București

Dermatita periorificială exfoliativă, mai ales la sugarul mic, asociată cu falimentul creşterii şi manifestări de malabsorbție, ridică o serie de probleme de diagnostic diferențial, fapt ce poate reprezenta o adevarată provocare.

Prezentăm cazul unui sugar în vârstă de două luni care s-a internat în Clinica noastră cu edeme generalizate, faliment al creşterii, dermatită periorificială şi acrală extinsă, tegumente palide şi tendință la echimoze.

Tabloul clinic şi biologic - anemie, trombocitopenie, hipoalbuminemie - de la internare au pus următoarele probleme de diagnostic diferențial

- septicemie

- intoleranță la PLV

- boli metabolice pentru care s-a efectuat screening extins completat de screeningul aminoacizilor urinări necesitând excluderea unor deficite de biotină întalnite în deficitul de holocarboxilază sau biotinidază, de B12 sau izoleucină din aciduriile organice de tipul citrullinemiei, acidemiei metilmalonice sau propionice şi bolii urinilor $\mathrm{cu}$ miros de sirop de arțar, deficit de acizi graşi esențiali, tirozinemie, deficit de zinc ca în acrodermatita enteropatică

- hipotiroidism

De asemenea, încă de la internare s-a ridicat suspiciunea de fibroză chistică pentru care s-au efectuat testare genetică şi testul sudorii.

În urma investigațiilor efectuate se confirmă diagnosticul de fibroză chistică.

\section{Acrodermatitis enteropathica-like eruption case presentation}

Periorificial exfoliative/exsudatevie dermatitis, especially in the little infant, in association with failure to thrive and malabsorbtion, raise a series of differential diagnostic problems which may represent a real challenge.

We present the case of a two months old infant hospitalized in our clinic with generalized edemas, failure to thrive, periorificial and acral extensive dermatitis, pale skin and mucosa and relatively easy bruising. 
The clinical and biological aspects - anemia, thrombocytopenia, hypoalbuminemia - at hospitalization needed taking into discussion the following

- sepsis

- cow's milk proteins allergy/intolerance

- metabolic diseases for which we performed extensive screening completed by urinary aminioacids screening - as we had to exclude biotin deficiency caused by holocarboxylase deficiency and biotinidase deficiency, B12 and isoleucine deficiency met in organic acidurias, citrullinemia, maple syrup urine disease, methylmalonic or propionic acidemias, essencial fatty acids deficiency, tyrosinemia, zinc deficiency present in acrodermatitis enteropathica

- hypotiroidism

Also, at the moment of admission, we raised the suspicion of cystic fibrosis for which we performed genetic testing and sweat test.

Following the results of all investigations we diagnosed cystic fibrosis.

\section{IMPORTANȚA CLINICĂ A DIFERITELOR TIPURI DE HEMOGLOBINĂ ŞI HEMOGLOBINOPATIILE}

Bioch. Corina Delia, Chimist Geanina Toma, Dr. Anca Ghiță

IOMC „Alfred Rusescu“, București

Hemoglobinopatiile sunt defecte genetice care constau în sinteza anormală (d.p.d.v. calitativ sau cantitativ) a lanțurilor de globină din structura moleculei hemoglobinei cu transmitere autozomal recesivă. În prezent nu există o evidență exactă la nivel național a cazurilor de hemoglobinopatii. Însă, se estimează faptul că în România trăiesc 240 de pacienți cu talasemie majoră.

Ținând cont de gravitatea bolii, sub aspectul manifestării clinice, precum şi de cel al implicațiilor datorate valorii ridicate a costurilor tratamentului, este absolut necesară efectuarea unei evaluări a riscului de apariție a pacienților cu forme majore. Prezenta lucrare îşi propune realizarea unei centralizări a tuturor hemoglobinopatiilor, descoperite în cadrul Laboratorul IOMC în perioada 2005-2013. Este mai uşor să previi decât să tratezi - depistarea la timp a formelor heterozigote va reduce riscul de apariție a formelor homozigote.

Subliniez importanța deosebită pe care o au rezultatele analizelor de laborator în stabilirea corectă a diagnosticului de hemoglobinopatie.

Deși numărul de 1.666 de pacienți considerați în calcul în acest studiu, în cadrul laboratorului de analize medicale al IOMC, poate părea insuficient pentru o analiză statistică, rezultatele au condus la identificarea unui număr de 715 de pacienți, număr important ca pondere, care prezintă diferite patologii.

Cunoaşterea frecvenței şi heterogenitații hemoglobinopatiilor în populația României este o condiție esențială pentru planificarea unei strategii adecvate destinate identificării purtătorilor.

În acest scop, programele de screening pot ajuta la prevenirea apariției formelor majore ale acestor boli.

În prezent, prin utilizarea aparaturii folosite în mod uzual în laboratorul de analize medicale, depistarea clinică a bolii nu mai constituie o problemă. Costurile investigațiilor necesare stabilirii diagnosticului sunt mai mici dacât al tratamentului pacienților cu forme majore şi justifică necesitatea şi importanța analizelor.

Efectuarea şi interpretarea corectă a unei hemograme înainte de căsătorie pot identifica prezența unor potențiale hemoglobinopatii, evitând astfel riscul apariției de descendenți cu forme cu afectare clinică majoră.

Rezultatele obținute impun continuarea studiului şi demararea unui program național de testare în vederea depistării hemoglobinopatiilor.

\section{Clinical importance of different types of hemoglobin and hemoglobinopathies}

Hemoglobinopathies are genetic defects consisting in abnormal synthesis (taking qualitatively or quantitatively) of the globin chains of the hemoglobin molecule structure with autosomal recessive transmission. Currently there are no accurate records of national cases of hemoglobinopathies. However, it is estimated that 240 patients in Romania are living with major thalassemia.

Given the severity of the disease in terms of clinical manifestation and the high cost implications due to the value of treatment is absolutely necessary to carry out a risk assessment for patients with major forms. This paper aims to achieve a centralization of all hemoglobinopathies discovered in the laboratory of IOMC in the period 20052013. It is easier to prevent than to treat - timely detection of heterozygous forms will reduce the risk of homozygous forms.

I emphasize the importance of the test results in correct diagnosis of hemoglobinopathy.

Although the number of patients (1666) considered in the calculation in this study in the laboratory of IOMC medical analysis, may seem insufficient for statistical analysis, the results led to the identification of 715 patients and show an important number for different pathologies.

Knowing the frequency and hemoglobinopathies types in the Romanian population heterogenity is a prerequisite for planning an appropriate strategy to identify carriers.

For this purpose, screening programs can help prevent major forms of these diseases. 
Currently, using commonly equipment in medical analysis laboratory, clinical detection of the disease is no longer a problem. The costs of necessary investigations are lower than the treatament of patients with major forms and justify the need and importance of the analysis.

Making the analise and the correct interpretation of it can identify the presence of potential homoglobinopathies, thus avoiding the risk of offspring with severe clinical forms.

The results require further study and the start of a national program of testing in order to identify hemoglobinopathies.

\section{INTERVENTIIA TIMPURIE ÎN ECHIPĂ INTERDISCIPLINARĂ LA COPIII CU RISC PENTRU PROBLEME DE SĂNĂTATE MINTALĂ}

Miruna Rădan, Mihaela Găișteanu, Dafina Ionuțiu, Raluca Vărășteanu, Iosefina Vaman

IOMC „Alfred Rusescu“, București

Scopul lucrării este prezentarea procesului intervenției timpurii pentru copiii cu dizabilități şi risc în dezvoltarea neuropsihică, din perspectiva echipei şi a funcționării ei, şi, în paralel, relevarea modului în care s-au dezvoltat serviciile oferite de Centrul de Sănătate Mintală şi strategia de abordare a intervenției, în funcție de nevoi şi resurse, îmbinând activitățile clinice-terapeutice şi de cele de cercetare.

Abordarea terapeutică timpurie, în parteneriat cu familia, stă la baza serviciilor oferite pentru copiii cu dizabilități multiple. Echipa cuprinde nucleul de neuropsihiatrie, o componentă de balneo-fizioterapie şi una educațional-terapeutică, cu competențe în metodologia interdisciplinară, terapie comportamentală, evaluare şi terapie precoce, cercetare. CSM dispune de un Centru de zi pentru copii cu dizabilități multiple şi tulburări din spectrul autist. Programele de intervenție vizează toate ariile dezvoltării copilului, sub formă de: (1) Intervenție precoce 0-3 ani (terapie funcțională de dezvoltare, terapie comportamentală şi terapie părinte-copil), (2) Terapie educațională în grup mic, 3-6/7 ani, (3) Logopedie, stimularea comunicării şi comunicare augmentativă, programul PECS, (4) Terapie comportamentală şi psihoterapie, (5) Consiliere, parenting şi tehnici de management comportamental, individual şi în grup. Serviciile s-au dezvoltat folosind rezultatele proiectelor de cercetare, cum sunt „Un model de intervenție interdisciplinară pentru copiii cu dizabilități multiple" şi „Tulburările din spectrul autist şi modelul funcțional de intervenție timpurie“. Programele actuale vizează atât dezvoltarea de noi competențe terapeutice în echipă, cât şi implementarea de programe specifice pentru anumite categorii de copii, „Picture Exchange Communication System“, precum şi compo- nente structurate pentru părinți - „Programul de parenting pozitiv pentru părinții care au copii cu dizabilități“.

\section{Early interdisciplinary intervention for children at risk for mental health problems}

The main goal of this paper is to present the early intervention process, aimed for disabled children and children at risk in neuropsychic development, with an emphasis on the team dynamics. We will also focus on how the intervention approach and the Mental Health Center (MHC) services evolved, according to the needs and resources, based on the clinical and the research activities interconnections.

The MHC promotes the parent-professional partnership model in early intervention. The team comprises several components: 1) mental health, 2) balneology-physiotherapy and physical therapy, 3 ) education and therapy. The professionals have special training in the fields of: interdisciplinary team intervention, behavior therapy, early intervention and research. The MHC includes a Day Center for multiply disabled and ASD children. Our intervention programs involve all developmental areas. We provide (1) Early intervention for 0-3 aged children, based on functional developmental therapy, behavior therapy and parentchild therapy, (2) Educational group therapy for 3-7 aged children, (3) Speech and language therapy and augmentative communication PECS, (4) Behavior therapy and psychotherapy, (5) Counseling, parenting and behavior management for parents (individual and group sessions). The services for children and families were developed based on our research projects results, such as: "An interdisciplinary intervention model for multiply disabled children" and "Autistic spectrum disorders and the functional early intervention model". Currently we aim to develop new specific intervention skills for our team members, to implement special programs for children, such as "The Picture Exchange Communication System", and to offer structured services for parents, such as "The Positive Parenting Program".

\section{DIAGNOSTICUL ŞI TRATAMENTUL ASTMULUI LA VÂRSTA PREŞCOLARĂ}

Conf. Dr. Ioan Cernatescu

IOMC „Alfred Rusescu“, București

Introducere. Motivația acestui articol pleacă de la o observație mai veche şi care este confirmată din plin în prezent: abuzul fără precedent de medicație antiastmatică la preşcolarul suspectat de astm. Această afirmație este susținută de mari personalități. lată ce spune A. Bush, citez: „Populația cea mai vulnerabilă din UE, copilul bolnav este 
tratat fără să se țină cont de studii bazate pe dovezi specific vârstei. Chiar medicația „banală“ beta-2 adrenergicele de scurtă durată şi antipireticele nu sunt adecvat studiate complet la vârsta $<2$ ani.

Studiul este retrospectiv, statistic şi cuprinde o perioadă de 5 ani (2009-2013).

Rezultate. Peste $1 / 2$ din consultații $(52,12 \%)$ au fost acordate la grupa de vârsta 1-5 ani, iar după vârsta de 5 ani = 47,87\%. Deci lotul de studiou cuprinde 2.744 de preşcolari (52,12\%) în intervalul 2009-2013 şi poate fi considerat un lot semnificativ statistic. Au fost 4 tipuri de diagnostic (aşa cum reiese din biletul de trimitere): astm $=32,4 \%$, tuse cronică $=30,33 \%$, wheezing recurent $=27,24 \%$ şi rinită alergică $=9,97 \%$. Diagnosticul de astm la grupa de vârstă 0-5 ani $(18,8 \%)$ necesită investigații specifice: analiza volumului curent (la sugar), rezistență oscilatorie (la vârsta 2-4 ani), testarea reversibilității, măsurarea $\mathrm{Fe}(\mathrm{NO})$ offline şi studii alergologice. În funcție de rezultatele acestor investigații se poate susține diagnosticul de astm la această vârstă.

Concluzii. Diagnosticul astmului la vârsta preşcolară necesită investigații specifice accesibile numai unor centre specializate. Administrarea de rutină a medicației antiastmatice: beta-2 adrenergice şi mai ales a corticoizilor sistemici pentru o tuse izolată sau răceli repetate poate conduce la reacții adverse cu consecințe imprevizibile la această grupă de vârstă.

\section{Management of asthma in preschool children}

Introduction. Unfortunately, in preschool children many physicians use the asthma therapy for symptoms like cough or rhinitis. "It has long been known that $50-90 \%$ of medications used in children are "off-label" or unlicensed, and this is associated with an increased risk of adverse events, the effects if inappropriately prescribed inhaled steroids on growth is well known, but even the use of parenteral steroids could affect alveolar development in the first 2 years of life - A. Bush".

A retrospective study was conducted between 20092013 in Lung Function Department from IOMC. 2,744 preschool children were included in this study.

The most important diagnosis were: asthma (32.4\%), chronic cough $(30.33 \%)$, reccurent wheezing $(27.24 \%)$, allergic rhinitis (9.57\%).

Specific investigations for diagnostic of asthma in preschool children (18.8\%) is needed. This investigations include: Tidal Breath Analysis, Oscillatory Resistance Test, Reversibility Test, Fe(NO) offline measurements and allergic tests. Unfortunately, only few pediatric departments may use all of them. For this reason, diagnostic of asthma in preschool was very difficult.

Conclusion. Asthma diagnostic in preschool children may be obtained after complex investigations. Some medications like: beta- 2 agonists, inhaled corticoids or systemic corticoids may produce dangerous adverse effects if used for common cold, cough or rhinitis.

\section{ANTIBIOTICOTERAPIA INHALATORIE ÎN FIBROZA CHISTICĂ - EXPERIENTTA IOMC}

Iustina Stan, Mihai Craiu, Ana-Maria Vasile, Denisa Leu, Doina Cană, Valentina Comănici

IOMC „Alfred Rusescu“, București

Context. La pacienții cu fibroză chistică (FC) leziunile pulmonare secundare infecției cronice reprezintă cauza principală de deteriorare a funcției pulmonare. La pacienții infectați cronic cu PA, administrarea de antibiotice pe cale inhalatorie a devenit regulă și standard de îngrijire. În România sunt disponibile: tobramicina și colistin.

Obiectiv. Studiu retrospectiv pentru aprecierea reducerii frecvenței exacerbărilor infecțioase pulmonare, ameliorarea funcției pulmonare, a calității vieții, aprecierea efectelor adverse.

Material şi metodă. Studiu retrospectiv pe o perioadă de 3 ani, la 22 de pacienți infectați cronic cu PA. S-au apreciat: datele clinice, funcția pulmonară, radiologic, culturi PA, numărul de exacerbări cu spitalizare, efecte adverse. Pacienții au primit o parte colistin - 8 pacienți şi TOBI - 14 pacienți.

Rezultate. Am evaluat cei 22 de pacienți pe parcursul a 246 vizite, vârsta pacienților a fost între 1 an și 33 de ani. Analiza funcției pulmonare la acești pacienți s-a efectuat la intervale de 6 luni. La pacienții tratați cu TOBI se constată - o creștere a FEV 1 cu 10\% la peste 50\% dintre pacienți, menținerea funcției pulmonare $-10 \%$, mai ales la cei cu funcție pulmonară sever afectată, numărul spitalizarilor a scăzut cu $25 \%$, efecte adverse la 3 pacienți (14\%). La pacienții cu colistin inhalator - menținerea FEV1 la 43\%, scăderea FEV1 cu $10 \%$ la 5 cu trecerea pe TOBI, creșterea numărului de spitalizări cu $12 \%$.

\section{Concluzii}

1. Administrarea regulată pe termen lung este sigură

2. Tratamentul inițial a fost cu colistin

3. Trecerea la TOBI s-a făcut în caz de evoluție nesatisfăcătoare

4. Evoluția în timp a FEV1 pare să indice o superioritate a TOBI

Cuvinte cheie: $T O B I$, colistin, infecție cronică cu $P A$,

FEV1

\section{Inhaled antibiotherapy in cystic fibrosis - Mother and Child Care Institute's experience}

Background. In cystic fibrosis (CF) patients, the main cause of pulmonary function decline is represented by sec- 
ondary pulmonary lesions due to chronic infection. Administration of inhaled antibiotics has become a gold standard in PA chronic infected patients. Inhaled Tobramycin and Colistin are available in Romania.

Objective. Retrospective study to evaluate the frequency reduction in infectious pulmonary exacerbations, improvement of pulmonary function, quality of life, assesement of adverse reactions.

Material and method. 3 years retrospective study in 22 PA chronic infected patients. We evaluated: clinical data, pulmonary function, $x$-ray, PA cultures, number of exacerbations that required hospitalization, adverse reactions. 8 patients received Colistin, 14 patients -TOBI.

Results. 22 patients aged between 1-33 years were evaluated on 246 visits. We evaluated pulmonary function every 6 months. In the TOBI group we observed a 10\% growth of FEV1 on more than $50 \%$ of patients, maintenance of the pulmonary function in $10 \%$ of them, especially on those with a severely affected pulmonary function, $25 \%$ drop on hospitalization rate, adverse reaction in 3 patients (14\%). In the Colistin group: maintenance of FEV1 in $43 \%$ of them, $10 \%$ FEV1 decline in 5 patients which imposed transition on TOBI, a $12 \%$ growth in the number of hospitalization.

\section{Conclusions}

1. Regulary, long-term administration is safe

2. Initially the treatment was started with colistin

3. Transition to TOBI was made in case of unsatisfactory evolution

4. FEV1 evolution in time seems to indicate a superiority of TOBI

Keywords: TOBI, colistin, PA chronic infection, FEV1

\section{ABPA ÎN FIBROZA CHISTICĂ - O RARITATE?}

Iustina Stan, Mihai Craiu, Ana Maria Vasile, Valentina-Daniela Comănici

IOMC „Alfred Rusescu“, București

Aspergiloza bronhopulmonară (ABPA) este o complicație survenită în evoluția pacienților cu fibroză chistică. Aspergillus fumigatus (Af) este un fung saprofit ce se găseşte în sol, apa, praf, vegetație. În organismul uman poate determina: colonizare, bronşită sau infecție pulmonară invazivă. Af acționează ca un alergen ce induce reacție de hipersenzitivitate cu eliberare de IgE specifice. Boala se defineşte prin criterii clinice (sindrom pulmonar obstructiv astmalike ce nu răspunde la tratament complex şi corect, febră; malaise; spută cenuşie) şi criterii paraclinice majore (radiologic - aspect caracteristic, evaluare computertomografică, creştere IgE totale $>500$ ui/L sau de $4 x$ valoarea anterioară, IgE specifice Af $>3$, eozinofilie, test cutanat Af pozitiv) şi minore (striații brune, negre în spută, test cutanat tardiv pozitiv, cultură pozitivă).

În IOMC în ultimii 5 ani au fost înregistrate 7 cazuri de aspergiloza bronhopulmonară la pacienții cu fibroză chistică (10\% dintre pacienți) cu repartiție egală pe sexe, evoluție favorabilă în 6 cazuri. Sunt prezentate particularități ale evoluției acestor pacienți cu evidențierea dificultăților de diagnostic şi de durată a tratamentului. Prevalența în IOMC este în intervalul acceptat în toată lumea (între $2 \%$ - SUA şi $15 \%$ - Belgia).

Pentru diagnosticul rapid al acestei afecțiuni se recomandă investigații țintite la pacienții cu grad de suspiciune ridicat prin determinarea IgE anual, dacă IgE $>1.500 \mathrm{IU} / \mathrm{mL}$ determinare IgE specifice Af, dacă există suspiciune clinică de aspergiloză bronhopulmonară (tuse accentuată, fenomene asthma-like nou apărute sau severe, astenie/scădere ponderală, febră) în absența dovezilor de exacerbare bacteriană.

\section{ABPA in cystic fibosis - a rare finding?}

Allergic Bronchopulmonary Aspergilosys (ABPA) is a complication in the evolution of cystic fibrosis (CF) patients. Aspergillus fumigatus (Af) is a saprophitic fungus that may be found in the soil, water, dust, vegetation. In the human organism it may cause: colonisation, bronchitis or invasive pulmonary infection. Af acts like an allergen that induces a hypersensitivity reaction causing specific IgE release.

The disease is characterised by clinical criteria (pulmonary obstructive syndrome asthma-like with poor response to complex and correct treatment, fever, malaise and gray sputum), major laboratory criteria (X-ray - characteristic aspect, CT evaluation, total IgE growth $>500 \mathrm{UI} / \mathrm{L}$ or four times baseline value, Af specific $\lg E>3$, eosinofilia, positive Af skin prick test) and minor laboratory criteria (brown/ black plugs in sputum, late skin test reaction, positive culture for Af).

In the last five years at the Mother and Child Care Institute there were 7 cases of ABPA in CF patients (10\% of the patients), with an equal gender repartition, and a favorable outcome in 6 cases. We have presented some particularities of these patients as diagnostic difficulties and treatment duration. The prevalence in our centre is within the acceptable international range (between $2 \%$ in the US and $15 \%$ in Belgium).

For a quick diagnosis of this complication we recommend targeted investigations in patients with a high degree of suspicion by determining total IgE levels annually. If the total IgE level > 1,500 UI/L we need to determine Af specific IgE if there is a clinical suspicion of ABPA (increased cough, emergent or severe asthma-like phenomenon, asthenia/weight, fever) in the absence of a bacterial exacerbation evidence. 


\section{CFTR-RELATED DISEASE, O NOUĂ PROVOCARE}

lustina Stan, Mihai Craiu,

Valentina Daniela Comănici, Ana Maria Vasile

IOMC „Alfred Rusescu“, București

Fibroza chistică este cea mai frecventă boală genetică monogenică cu transmitere autozomal recesivă la rasa caucaziană. În ultimii ani au fost descrise câteva boli legate de disfuncții ale CFTR fără a avea o clasificare unanim acceptată. În prezent sunt folosiți doi termeni în literatura de specialitate: CFTR - related disorders şi CFTR - metabolic syndrome. CFTR - related disorder pot fi definite ca entități clinice asociate cu disfuncții ale CFTR care nu îndeplinesc criteriile de diagnostic pentru fibroza chistică.

Pentru diagnosticul acestor entități pe lângă teste specifice (testul sudorii, diagnosticul molecular, potențiale nazale evocate) trebuie urmat un algoritm de diagnostic. Importanța diagnosticării acestor entități este reprezentată de impactul asupra tratamentului individualizat. Din grupul acestor boli fac parte pancreatitele recurente acute sau cronice, bronşiectaziile diseminate şi absența congenitală a vaselor deferente. Tabloul clinic clasic este reprezentat de pacientul cu manifestări clinice respiratorii sau digestive evocatorii pentu fibroza chistică dar cu testul sudorii negativ sau border-line. Din punct de vedere practic aceşti pacienți sunt considerați cu risc, necesitând controale periodice, supraveghere asemănătoare cu a pacienților cu fibroză chistică. În cazul manifestărilor clinice este prudentă abordarea terapeutică FC-like.

În ultimiii 3 ani în IOMC s-au realizat 30 de testări genetice la pacienți adulți şi copii care prezentau manifestări evocatorii pentru CFTR - related disorder. $80 \%$ dintre pacienții cu manifestări respiratorii au îndeplinit criteriile de diagnsotic, 2 dintre aceştia ulterior datorită completării tabloului cilinc au fost încadrați în fibroza chistică atipică. Dintre pacienții cu manifestări digestive şi cu testul sudorii border line doar 2 au îndeplinit criteriile de diagnostic ca CFTR related disorder şi dintre aceştia ulterior 1 a fost încadrat în fibroza chistică atipică.

\section{CFTR-related disease: a new challange}

Cystic fibrosis is the most common autosomal recessive monogenic disorder in caucasians. In the late years there were described a few disorders generated by CFTR disfunction without having an universally accepted classification.

Nowadays there are being used two terms in the literature: CFTR - related disorders and CFTR - metabolic syndrome. CFTR - related disorder can be defined as clinical entities associated with CFTR disfunctions that don't meet the diagnostic criteria for cystic fibrosis. For diagnosing these entities, among the specific tests (sweat test, molecular diagnostic, nasal evocated potentials) a diagnosis algorithm must be followed. It is important to diagnose these entities because of the impact of individualised treatment. This group includes: recurrent acute or chronic pancreatitis, disseminated bronchiectasies and congenital bilateral absence of the vas deferens. Classical clinical presentation: patient with respiratory or digestive clinical manifestations, evocative for cystic fibrosis, but with negative or borderline sweat test. On a practical point of view these patients are considered at risk, they need periodic checks and surveillance similar to CF patients. Regarding the clinical manifestations it is cautious to make a CF - like therapeutic approach.

At the Mother and Child Care Institute, in the last 3 years we had 30 genetic tests performed on adults and children that presented clinical manifestations evocative for CFTR - related disorder. Among them, $80 \%$ of the patients with respiratory manifestations met the diagnostic criteria, 2 of them were enclosed as atipical cystic fibrosis, after analysing the clinical manifestations. Among the patients with digestive manifestations and borderline sweat test only 2 met the diagnostic criteria for CFTR - related disorder, later on only one was enclosed as atipical cystic fibrosis.

\section{REGISTRUL NATIIONAL AL FEMEII GRAVIDE INFECTATE HIV ŞI AL NOU-NĂSCUTULUI EXPUS PERINTAL HIV - O NECESITATE PENTRU ROMÂNIA?}

Mariana Mărdărescu ${ }^{1,2}$, Cristina Petre ${ }^{1}$,

Ruxandra Drăghicenoiu ${ }^{1}$, Rodica Ungurianu ${ }^{1}$, Alina Cibea ${ }^{1}$, Carina Matei ${ }^{1}$, Sorin Petrea ${ }^{1}$, Ana Maria Tudor ${ }^{1}$, Delia Vlad ${ }^{1}$, Marieta lancu², Sanda Vintilă², Claudiu Mihai Șchiopu ${ }^{1}$, Alexandra Mărdărescuํㄹ Ioana Alina Anca ${ }^{3}$, Mihai Mitran ${ }^{4}$

IInstitutul Național de Boli Infectioase „Prof. Dr. Matei Balș“, București

${ }^{2}$ Compartimentul pentru evaluarea și Monitorizarea Infecției HIV/SIDA în România

${ }^{3}$ IOMC „Alfred Rusescu“, București

${ }^{4}$ Spitalul Clinic de Obstetrică și Ginecologie

„Prof. Dr. Panait Sârbu“, București

Introducere. Experiența ultimilor ani în managementul epidemiei HIV/SIDA şi modificarea comportamentală a populației tinere, consumatoare de droguri pe cale intravenoasă ne-a determinat să adaptăm îngrijirile acordate pacienților cu infecție HIV din cohorta 1987-1990. Aceasta 
prezintă o patologie complexă fiind multiexperimentată terapeutic, cu probleme de aderență şi rezistență la terapia specifică antiretrovirală, dar şi cu stadii avansate ale bolii. Mai mult, majoritatea a ajuns la vârsta fertilă, dând naştere unei noi generații de copii infectați HIV. Registrul Național al femeii gravide infectate HIV şi al nou-născutului expus perinatal HIV reprezintă un instrument de operare care colectează date despre mamă şi copil, al cărui rol esențial este de a crea o imagine de ansamblu asupra fenomenului transmiterii materno-fetale a virusului HIV. Registrul a fost lansat simultan cu un studiu prospectiv observațional, la data de 1 ianuarie 2014, care vizează gravida infectată HIV şi copii expuşi perinatal HIV, din toate regiunile țării.

Metode. Registrul stochează datele personale ale mamei şi copilului, istoricul medical al copilului, investigații la baseline, investigații clinice la 6 şi 18 luni de supraveghere, datele personale ale mamei, momentul diagnosticării $\mathrm{cu}$ infecție HIV, factori de risc, istoricul bolii şi istoricul terapeutic, investigații peripartum imunologice şi virologice, precum şi informații despre tată şi familie.

Rezultate. În perioada celor 9 luni de supraveghere (01.01-30.09.2014) am înregistrat 275 de cazuri de copii expuşi perinatal HIV. $30 \%$ provin din mame nou diagnosticate cu infecție HIV, 31\% din mame care aparțin cohortei 1987-1990. 19\% dintre copii au fost expuşi şi la drogurile consumate de mame, $16 \%$ la infecția HCV maternă, iar 22\% la infecția HBV. Din totalul copiilor, $7 \%$ au prezentat încărcătură virală detectabilă la naştere. $12 \%$ dintre mamele infectate HIV au fost considerate cazuri de prezentări tardive în sistemul sanitar.

Concluzii. Deşi în România screening-ul HIV este disponibil şi gratuit pentru toate gravidele, un număr mare de femei se prezintă târziu la spital pentru investigații, inclusiv cele pentru infecția HIV, ceea ce îngreunează aplicarea oricăror măsuri profilactice de reducere a transmiterii materno-fetale a HIV. Evaluarea primară, pe o perioadă de 9 luni, a relevat că dintr-un total de 275 de copii expuşi $6 \%$ au prezentat încărcătură virală detectabilă la primul test, având ca urmare statutul de copil infectat HIV.

\section{The National Registry of pregnant women infected with HIV and of perinatally exposed children - a need for Romania?}

Background. The recent years' experience made us face a new typology of HIV cases (the outbreak within the people who inject drugs) as well as the necessity to adapt specific cares to the needs of the patients coming from the 1987-1990 cohorts. The latter presents a complex pathology: they are therapeutically multi experienced, have adherence and ART resistance problems and experience advanced stages of disease. Furthermore, most of them have reached a fertile age, giving birth to a new generation of
HIV children, which makes us update our approach to HIV infection. The National Registry of pregnant women- infected with HIV and of perinatally exposed children represents an operational tool that collects data on the item "motherchild", whose main role is to clearly display a national overview on the phenomenon of mother to child transmission. The registry sides with a prospective observational study launched at 1 January 2014 that focuses on pregnant women and HIV exposed children from all the regions in Romania.

Methods. The Registry stores personal data on both mothers and children, the child's medical history (physiological and pathology data), initial investigations, investigations at 6 and 18 months of surveillance; the mother's personal data, time of HIV diagnosis, risk factors, disease and therapeutic history, peripartum immunological and virological investigation, as well as information about the father and siblings.

Results. Throughout 9 months of reporting we registered 275 cases of exposed children. $30 \%$ come from newly detected mothers, $31 \%$ from mothers belonging to the 1987-1990 cohorts. $19 \%$ of children were also exposed to the drugs their mothers used, $16 \%$ to the mothers' $\mathrm{HCV}$ and $22 \%$ to HBV. From the total number of children $7 \%$ had detectable viral load at birth. $12 \%$ of mothers with HIV infection were considered late presenters.

Conclusion. Although HIV screening for pregnant women is free and universal in Romania, a high number of women are late presenters, which hinders any prophylactic measure to reduce the transmission of HIV from mother to child. Our 9 months assessment reveals that out of 275 exposed children, $6 \%$ presented detectable viral loads at the first screening. In all these cases the cause was the lack of or a precariously applied prophylaxis.

\section{ÎNGRIJIREA NOU-NĂSCUTULUI CU GREUTATE MAI MICĂ DE 1.500 DE GRAME VENTILAT CPAP-NAZAL}

Nadia-Alexandra Burlacu

Secția de Neonatologie, IOMC „Polizu“, București

Introducere. Îngrijirea nou-născutului cu greutate mai mică de 1.500 de grame ventilat CPAP-nazal presupune cunoaşterea dispozitivelor, cunoaşterea şi folosirea corectă a echipamentului de reanimare, pricepere în evaluarea clinică şi aplicarea corectă a tehnicilor de îngrijire specifice nou-născutului prematur.

Scop. Înțelegerea nevoilor nou-născuților cu greutate mai mică de 1.500 de grame

Material şi metode. S-au folosit date prelevate din protocoale neonatale, cărți şi articole de specialitate. 
Rezultate. Îngrijirile nou-născutului cu greutate mică la naştere care necesită suport ventilator sunt mai complexe decât îngrijirile acordate nou-născutului sănătos la termen.

Concluzii. Nou-născutul cu greutate mai mică de 1.500 de grame prezintă dificultăți de adaptare la viața extrauterină care sunt explicate prin imaturitate organică şi funcțională, necesitând de cele mai multe ori suport ventilator.

Managemantul corect al acestor nou-născuți necesită cunoaşterea unor metode de îngrijire specifică adaptate nevoilor speciale pe care vârsta mică de gestație şi greutatea scăzută le implică.

\section{Care of newborn weighing less than 1,500 grams with nasal CPAP ventilation}

Introduction. Care of the newborn weighing less than 1,500 grams with nasal CPAP ventilation requires knowledge of the devices, knowledge and proper use of resuscitation equipment, understanding the clinical evaluation and the correct techniques specific to the prematurely newborn care.

Aim. Understanding the needs of infants weighing less than 1,500 grams.

Material and methods. We used data collected from neonatal protocols, books and articles.

Results. Neonatal care of low birth weight newborn who require ventilator support are more complex than the ones given to the healthy newborn.

Conclusions. New baby weighing less than 1,500 grams have difficulty adjusting to life outside the womb which explains the organic and functional immaturity, often requiring a ventilator support.

Responsible management of these infants requires accurate knowledge of the methods of care, tailored to specific special young age of gestation and low weight involved.

\section{TEHNICI DE ÎNGRIJIRE A COPILULUI CU ILEOSTOMĂ}

\author{
As. Daniela Nistor
}

IOMC „Alfred Rusescu“, București

lleostoma presupune îngrijiri speciale:

Ea nu afectează în mod semnificativ digestia.

Este important să se evite mesele abundente, iar consumul alimentelor să se facă încet (în cazul lucrării prezentate copilul este alimentat prin gavaj pe injectomat).

Mesele zilnice vor fi regulate.

În cazul ileostomei temporare pot aparea iritații ale tegumentului din jurul ileostomei.

Pentru aceasta trebuie îngrijit foarte bine tegumentul prin spălare şi hidratare adecvată, cu produse specifice ce vor fi livrate de producător odată cu punga colectoare pentru ileostomă.

În fiecare zi se va inspecta starea tegumentului şi se anunță medicul despre orice schimbare.

Toate tehnicile de îngrijire ale ileostomei (şi de golire a pungii colectoare) se vor face cât mai steril posibil şi întodeauna de două persoane (un asistent şi o infirmieră).

\section{Care of the child with ileostoma}

lleostoma requires special care.

It does not significantly affect digestion. It is important to avoid heavy meals and food consumption should be slowly made (if the child presented paper is fed by gavage on the syringe).

Daily meals will be regular. In case of temporary ileostoma, skin irritation may occur around.This requires great care and adequate hydration of the skin by washing and hydration with specific products, which are supplied by the manufacturer together with the ileostoma bag

The skin condition should be inspected every day and any changes should be reported to the physician.

All of ileostoma care techniques (and emptying the bag collectors) will be made as sterile as possible and always by two persons (nurse and a care taker).

\section{MANAGEMENTUL ABORDULUI VENOS PERIFERIC LA COPIL}

Asist. lic. pr. Rodica Noaje

Secția clinică pediatrie IV, IOMC, București

Abordul venos periferic include şi cateterizarea unei vene periferice prin poziționarea unui tub/cateter în venă. Cateterul venos este un dispozitiv non toxic, steril, non pirogen; este atraumatic şi perfect adaptat pentru fixarea şi orientarea pe traiectul venos, fără a risca vătămarea venei.

Plasarea cateterului este o manevră invazivă, cu riscuri şi complicații, care trebuie efectuată în siguranță de către personal medical instruit şi utilizând tehnică sterilă.

Abordul venos poate fi efectuat periferic sau central. Abordul venos periferic este realizat de către asistenta medicală, iar cel central numai de către medic. Cateterizarea percutană reprezintă abordul vascular cel mai utilizat, înlocuind tehnica denudării prin manevre chirurgicale.

Alegerea tipului de abord şi a locului de elecție depinde de:

- starea clinică a pacientului şi criteriul de urgență;

- tipul medicamentului şi efectul scontat;

- cantitatea de administrat, durata tratamentului.

Scopul abordului venos poate fi de:

- prelevare de sânge, pentru analize curente; 
- administrarea i.v. de preparate, în scop diagnostic;

- monitorizarea parametrilor sanguini;

- resuscitare cardiorespiratorie.

Calea venoasă periferică prezintă un risc infecțios mai mic şi complicații mai puține, de severitate mai redusă, este mai uşor de montat şi supravegheat comparativ cu calea venoasă centrală, dar necesită schimbare mai frecventă.

Echipa de lucru în pediatrie este formată din asistentă şi infirmieră.

Pentru puncționarea venelor periferice se preferă sistemul venos cav superior, printr-o abordare centripetă, deoarece obliterarea de la început a venelor de la plica cotului compromite posibilitatea de utilizare a venelor distale. Sistemul venos cav inferior este mai puțin evident, fluxul sanguin este mai scăzut, riscul de lezare sau trombozare a vaselor fiind mai mare. La copii, pentru perioade scurte de timp, se utilizează orice venă abordabilă, inclusiv a membrelor inferioare, venele epicraniene, vena jugulară externă. Procedura se execută într-un departament de prespital şi/ sau spital.

Rolul asistentei în mana gementul abordului venos periferic la copil se referă la:

- pregătirea materialelor sterile şi nesterile;

- pregătirea fizică şi psihică a copilului;

- respectarea măsurilor de asepsie;

- monitorizarea liniilor venoase în zona de inserție;

- supravegherea în vederea depistării complicațiilor posibile legate de modul de administrare a soluțiilor;

- creşterea satisfacției pacienților prin reducerea numărului de încercări reuşite de efectuare a puncției;

- utilizarea tehnicilor de vizualizare a venelor;

- folosirea dispozitivelor care introduc în țesut o cantitate redusă de anestezic local, pentru a atenua durerea injecției;

- reducerea durerii prin modificarea practicilor folosite, deoarece pe termen lung, memoria experiențelor dureroase, are influență atât asupra percepțiilor dureroase următoare, cât şi asupra răspunsului la durere.

\section{Management of the peripheral venous approach at child}

Peripheral venous approach includes also peripheral venous catheterization of a vein by positioning a tube/ catheter into a vein. Venous catheter is a non toxic, sterile, non pyrogenic device; is atraumatic and perfectly adapted for attachment and orientation on the venous path without risking vein injury. Catheter placement is an invasive maneuver, with risks and complications that must safely performed by trained medical staff using sterile technique. Venous can be performed peripheral or central. Peripheral venous is conducted by the nurse, and the central one only by the doctor. Percutaneous catheterization is the mostly used vascular access, replacing the denudation technique of surgical maneuvers.
The choice of approach and place of choice depends on: - Condition of the patient and emergency criterion;

- Type of product and the desired effect;

- The amount to be given, the duration of the treatment.

The purpose of the venous approach can be:

- Blood sampling for the current analysis;

- IV administration of preparations for diagnostic purposes;

- Monitoring of blood parameters;

- Cardiopulmonary resuscitation.

The peripheral venous line shows less infectious risk and fewer complications, of lower severity, it is easier to install and supervised versus intravenous middle route, but requires more frequent change.

The working team consists of a nurse and a care giver.

For the puncture of peripheral veins it is preferred the higher hollow venous system through a centripetal approach because the from the beginning vein obliteration of the fold of the elbow compromises the usability of the distal veins. The lower hollow vein is less obvious, blood flow is lower, the risk of injury or thrombosis of vessels being higher. At children, for short periods of time, any approachable vein is used, including the ones from legs, the epicranien veins, external jugular vein.

The procedure is conducted in a pre-hospital department and/or hospital.

The role of the nurse in the management of peripheral intravenous line at children refers to:

- Sterile and non-sterile preparation materials;

- Physical and psychological preparation of the child;

- Compliance with aseptic measures;

- Monitoring venous lines in insertion area;

- Monitoring in order to detect possible complications related to the mode of injection management;

- Increasing patient satisfaction by reducing the number of successful puncture attempts;

- Use veins visualization techniques;

- Use of devices that introduce in tissue a small amount of local anesthetic to alleviate the injection pain;

- Reduce pain by changing the used practices because long-term memory of painful experiences has influence both on the future perceptions and on the response to pain.

\section{INIȚIERE ÎN RETINOPATIA DE PREMATURITATE}

As. Iulia Cotan, As. Ioana Andrei

IOMC „Alfred Rusescu“, București

Retinopatia de prematuritate este o boală proliferativă multifactorială, care afectează vascularizația retiniană imatură a nou-născutului prematur. 
În țările dezvoltate şi cele în curs de dezvoltare retinopatia de prematuritate se situează în primele locuri ca şi cauză de cecitate la copil (în USA ocupă locul 2).

Se discută istoricul bolii, etiopatogenia acesteia legată de teoria hiperoxie-hipoxie.

Se explică stadializarea bolii ( 5 stadii evolutive), localizarea acesteia pe zone retiniene ( 3 zone pornind de la nervul optic până la periferia retinei) şi extinderea ei (pe 12 ore de ceas).

Criteriile de screening în țara noastră sunt: toți prematurii cu Gn $\leq 2.000 \mathrm{~g}$ şi/sau VG $\leq$ săptămâni de gestatie, dar şi cei care depăşesc aceste criterii având o patologie peri şi postnatală gravă ( $G n$ = greutate la naştere; VG = vârsta gestațională).

Prima examinare se face la 4-6 săptămâni postnatale sau 31 săptămâni postconcepționale, oricare din aceste date apare mai târziu

Se prezintă factorii de risc ai bolii, printre care amintim prematuritatea extremă, oxigenoterapia cu $\mathrm{FiO} 2 \geq 40 \%$, ventilația mecanică, septicemia, anemia, hemoragiile intraventriculare.

Se explică tehnica de examinare prin oftalmoscopie indirectă sub anestezie locală.

Tratamentul actual al bolii se face prin fotocoagulare laser al retinei avasculare şi, în unele forme severe în zona I, prin injecție intravitreană cu bevacizumab (terapie antiVEGF)

Screeningul retinopatiei de prematuritate din țara noastră a înregistrat un număr din ce în ce mai mare de prematuri testați (718 în 2005 la 2959 în 2013), numărul celor tratați crescând şi el progresiv (48 în 2005 la 135 în 2013).

\section{Getting started with prematurity retinopathy}

Retinopathy of prematurity is a proliferative multifactorial disease, which affects the immature retinal vasculature of the premature newborn. In developed and developing retinopathy of prematurity is in the first place as a cause of blindness in children (in the USA ranks 2).

The history of the disease is discussed, its etiopathogenesis, hyperoxia, hypoxia related theory. It is explained the disease stage ( 5 stages of evolution), its location on retinal areas ( 3 zones from the optic nerve to edge retina) and its extension ( 12 hours clock). The screening criteria in our country are: all premature infants with $\mathrm{Gn} \leq 2,000 \mathrm{~g}$ and/or VG $\leq$ weeks of gestation, and those who exceed these criteria having a peri and postnatal serious pathology ( $G n=$ weight at birth; $V G=$ gestational age).

The first examination is 4-6 postnatal weeks or 31 weeks postconceptional, whichever later occurs. It presents risk factors for the disease, among which extreme prematurity, oxygen therapy with $\mathrm{FiO} 2 \geq 40 \%$, mechanical ventilation, sepsis, anemia, intraventricular hemorrhage. It explains the indirect ophthalmoscopy examination technique under local anesthesia. The current treatment of the disease is made by laser photocoagulation of retinal avascular and in some severe in zone I, intravitreal injection of bevacizumab (anti-VEGF therapy) Screening for retinopathy of prematurity in our country reported an increasingly number of tested premature (718 in 2005-2959 to 2013), the number of treated also gradually increasing (48 in 2005 to 135 in 2013).

\section{PNEUMONIILE ÎN PRACTICA PEDIATRICĂ}

Nela Apostol, Daniela lordan

IOMC „Alfred Rusescu“, București

- Afecțiuni acute ale parenchimului pulmonar caracterizate de:

$-+/$ - Proces inflamator alveolar

- +/- Afectare interstițială pulmonară

- Etiologia este diferită, în funcție de grupa de vârstă:

* 0-1 lună

* 1-3 luni

$* 4$ luni -5 ani

* 5-15 ani

- 0-1 lună

* Virusuri: CMV, rubeola, herpes simplex

* Bacterii: GBS, E. coli, Listeria, stafilococ auriu. Pseudomonas aeroginosa, enterobacterii

* Altele: Chlamydia trachomatis, Treponema pallidum

-1-3 luni

* Altele: Chlamydia trachomatis

* Virusuri: VSR, V paragripal 3

* Bacterii: Bordetella pertussis, stafilococ auriu, pneumococ

- 4 luni -5 ani

* Virusuri: VSR, V gripal, paragripal, rinovirusuri, adenovirusuri

* Bacterii: pneumococ, Haemophillus influenze, stafilococ auriu, Mycoplasma pneumoniae

* Altele: TBC

- 5-15 ani

* Virusuri: V gripal, paragripal, rinovirusuri, adenovirusuri sau mixte (vir + bact) în 23\% dintre cazuri.

* Bacterii: Mycoplasma pn., Chlamydia pn., pneumococ

* Altele: TBC

- Detresă respiratorie

* tiraj intercostal

* tiraj suprasternal

* înfundare sternală

- Puls-oximetria (cea mai utilă pentru prognostic)

$*>92 \%$ în aer atmosferic $=\mathrm{N}$

* Ideal $>95 \%$

-Astrup 
* ph 7,35-7,45

$* \mathrm{PaO} 2>50 \mathrm{~mm} \mathrm{Hg}$

* PaCO2 $40 \mathrm{~mm} \mathrm{Hg}$

Complicații. Pneumotorax

\section{Pneumonia in pediatric practice}

- Acute lung parenchyma characterized by:

- +/- Alveolar inflammatory process

-+ - Interstitial pulmonary impairment

- The etiology is different, depending on the age group:

* 0-1 month

* 1-3 months

$* 4$ months -5 years

* 5 -15 years

- A -1 months

* Viruses: CMV, rubella, herpes simplex

* Bacteria: GBS, E coli, Listeria, Staph. au., Pseudomonas aeroginosa, Enterobacteriaceae

* Other: Chlamydia trachomatis, Treponema pallidum

-1-3 months

* Other: Chlamydia trachomatis

* Viruses: RSV, parainfluenza $3 \mathrm{~V}$

* Bacteria: Bordetella pertussis, Staph aureus, Pneumococcus

- 4 months -5 years

* Viruses: RSV, V influenza, parainfluenza, rhinovirus, adenovirus

* Bacteria: Pneumococcus, Haemophilus influenze. Staphilococcus aureus, Mycoplasma pneumoniae

* Other: TBC

- 5-15 years

* Viruses: V influenza, parainfluenza, rhinovir, adenoviruses or mixed (vir + bact) in $23 \%$ of cases.

* Bacteria: Mycoplasma pn, pn Chlamydia, Pneumococcus

* Other: TBC

- Respiratory distress

* Printing intercostal

* Suprasternal

* Clogging sternal

- Puls- oximetry (most useful for pron.)

$*>92 \%$ in room air $=\mathrm{N}$

$*$ Ideal $>95 \%$

- Astrup

* PH 7.35 to 7.45

* $\mathrm{PaO} 2>50 \mathrm{~mm} \mathrm{Hg}$

* PaCO2 $40 \mathrm{~mm} \mathrm{Hg}$

Complications. Pneumothorax

\section{ŞCOALA PĂRINȚILOR}

Oana Maria Clocotici, Dr. Ecaterina Stativă, Alma Ștefănescu

IOMC „Alfred Rusescu“, București

Context. "SScoala Părinților" este recunoscută a fi una din componentele îngrijirilor prenatale având un impact pe termen lung în sănătatea femeii, copilului şi familiei. Nevoile educaționale ale părintilor au evoluat de-a lungul timpului, iar numeroase studii au demonstrat beneficiile şcolii părinților asupra sănătătii copiilor, prin obținerea de către părinți a unor informații, într-o perioada de maximă receptivitate a acestora, perioada prenatală.

Începând cu anul 2010, „,Şcoala Părinților" este o activitate prevăzută în Programele Naționale de Sănătate.

Concepție şi desfăşurare. Prezenta lucrare îşi propune să prezinte experiența IOMC în organizarea şi desfăşurarea acestei activități.

Organizarea cursurilor a presupus mai multe etape:

1. Identificarea nevoilor educaționale ale părinților

2. Elaborarea tematicii şi a modului de desfăşurare

3. Pregătirea formatorilor

4. Monitorizarea şi evaluarea continuă a rezultatelor

Cursurile pentru părinți au fost desfăşurate în 5 module, cu formatori specializați pentru fiecare domeniu. Fiecare modul acoperă o tematică distinctă, adaptată nevoilor părinților şi copilului în perioada prenatală şi primii doi ani de viață ai copilului: importanța îngrijilor prenatale, fiziologia sarcinii, recomandări profilactice în sarcină, tehnici de gestionare a disconfortului în travaliului şi naştere, promovarea alăptării şi nutriția corectă a copilului, îngrijirea nounăscutului, drepturile mamei, a copilului şi a familiei, legislație etc.

Cursurile s-au desfăşurat într-o manieră interactivă, plecând de la nevoile educaționale ale părinților.

Rezultate. Evaluările realizate la terminarea cursurilor au arătat receptivitatea deosebită a părinților la mesajele fiecărui modul. Abordarea integrată a tematicilor fiecărui modul, a deschis dorința părinților în a-şi dezvolta continuu abilitățile parentale, pentru a putea susține competent dezvoltarea fizică, socială şi emoțională a copilului.

Una dintre limitele acestei activități a fost atragerea extrem de limitată a părinților din segmente defavorizate, deşi cursurile au fost gratuite.

Cuvinte cheie: Şcoala Părinților, dezvoltarea copilului, îngrijiri pre-şi postnatale

\section{Parenting prenatal classes}

Context. Parents prenatal courses are one of the components of prenatal care with a long-term impact on women's health, children and family. Parents' educational 
needs have evolved over time and many studies have demonstrated the benefits of Parents School on children's health by offering information to parents in a period of maximum receptivity, which is their prenatal time.

Since 2010, the Parents' School is an activity stipulated in National Health Programs.

Design. This paper aims to present IOMC experience in organizing and conducting this activity.

Organizing courses involved several steps:

1. Identifying the educational needs of parents

2. Developing the topic and the way it functions

3. Training of trainers

4. Monitoring and ongoing evaluation of results

Courses for parents were conducted in 5 modules with specialized trainers for each area. Each module covers a topic tailored to the needs of parents and children in the prenatal period till the first two years of a child's life: the importance of prenatal care, pregnancy physiology, prophylactic recommendations in pregnancy, discomfort management techniques in labor and birth, breastfeeding promotion and correct nutrition, newborn care, maternal child rights and family law etc.

Classes were held in an interactive manner according to the educational needs of parents.

Results. Evaluations conducted at the end of the course showed great receptivity to the messages of each module. Integrative approach on the specific topics of each module revealed for parents the desire to continuously develop their parenting skills in order to sustain the best of physical, social and emotional development for the child.

One of the limits of this activity was the lack of interest of the parents coming from disadvantaged segments, although the courses were free.

Keywords: Implementing parenting prenatal classes, child development, pre-and postnatal care

\section{ASPECTE PRIVIND ÎNGRIJIRILE PRENATALE ÎN ROMÂNIA}

Dr. Ecaterina Stativă, As. Oana Clocotici

IOMC „Alfred Rusescu“, București

Context. Scopul major al îngrijirilor prenatale este naşterea la termen a unui copil sănătos cu riscuri minime pentru mamă. În societățile moderne, îngrijirile prenatale sunt formalizate prin acte normative care stabilesc obiectivele şi conținuturile acestora. Evaluarea diferitelor modele de îngrijiri prenatale experimentate în timp evidențiază stadiul cunoaşterii în domeniu pentru anticiparea, prevenirea sau minimizarea problemelor, a morbidității sau mortalității materno-infantile. Adoptarea formală a unui model de îngrijire bazat pe dovezi ştiintifice nu se impune necondiționat în societate. Există o serie de bariere în utilizarea de către gravide a serviciilor prenatale.

Obiectiv. Prezentul studiu îşi propune să identifice modele de utilizare ale îngrijirilor prenatale experimentate de femeile din România, în funcție de caracteristicile sociodemografice ale acestora.

Metodă. A fost realizată o analiză secundară a datelor obținute de la două studii epidemiologice reprezentative pe țară, realizate în 2009 şi 2010. Datele studiilor au fost obținute de la un eşantion reprezentativ de femei de 400 femei aflate în perioada post partum, şi respectiv 914 femei, mame ale unor copii de cel mult 6 luni.

Rezultate. Între 6-7\% dintre femei nu au utilizat niciodată serviciile prenatale. Aceste femei cumulează mai multe elemente de defavorizare precum apartenența la un grup etnic defavorizat, anafabetism, vârsta mică, mamă singură, sărăcie. $80 \%$ dintre gravide se prezintă la prima vizită prenatală în primul trimestru de sarcină şi aproape şi $70 \%$ dintre ele realizează standardul de 8 vizite prenatale. Dar numai $14 \%$ dintre ele au realizat obiectivele fiecărei vizite prenatale aşa cum prevede stadardul actual adoptat de Ministerul Sănătății. Măsurat prin indicele Kotelckuck, doar $22 \%$ dintre gravide au beneficiat de îngrijiri adecvate. Din punct de vedere sociodemografic, educația este cel mai puternic factor de diferențiere între femei pentru şansa îngrijirilor adecvate.

Concluzii. Dezavantajele sociale acționează ca bariere în utilizarea serviciilor prenatale chiar dacă ele sunt universal gratuite, în România.

Nerealizarea obiectivelor fiecărei vizite la vârstele timpurii şi cheie ale sarcinii, chiar şi la femeile care realizează numărul recomandat de vizite prenatale, compromit posibilitatea anticipării riscurilor şi complicațiilor sau a intervențiilor pentru reducerea acestora.

\section{Aspects of prenatal care in Romania}

Context. The main goal of prenatal care is the birth of a healthy baby to term, with a minimum risk for mother. In modern societies prenatal care is formalized by laws which establish their objectives and contents. Evaluation of various models of prenatal care experienced over time highlights the state of knowledge in the field for anticipating, preventing or minimizing the problems, maternal and infant morbidity or mortality. Adopting a formal prenatal care model based on scientific evidence is not unconditionally required in society. There are a number of barriers for pregnant women to use prenatal services.

Objective. This study aims to identify patterns of use of prenatal care experienced by women in Romania, depending on their socio-demographic characteristics.

Methods. A secondary analysis was performed on the data obtained from two epidemiological studies represen- 
tative in the country, conducted in 2009 and 2010. Data was collected from a representative sample of women in post partum $N=400$, and 914 women, mothers of children of 6 months old.

Results. Between $6-7 \%$ of women have never used prenatal services. These women show more disadvantaged elements such as affiliation to an underprivileged ethnic group, illiteracy, young age, single mother, poverty. $80 \%$ of pregnant women present at the first prenatal visit in the first trimester of pregnancy and almost $70 \%$ of them achieved the standard 8 prenatal visits. Only $14 \%$ of them have achieved the objectives of each prenatal visit as required by current standard adopted by the Ministry of Health. Evaluated by Kotelckuck index, only $22 \%$ of preg- nant women received adequate prenatal care. In terms of socio-demographic, education is the most powerful differentiating factor between women for the adequate care chance.

Conclusions. Social disadvantages act as barriers to the use of prenatal services even if they are over all free in Romania.

Failure to achieve the objectives of each visit during early pregnancy stages, even for women who performed the recommended number of prenatal visits, compromise the possibility of risk complications predicting and of interventions to reduce them.

Keywords: prenatal care model, prenatal visits 